University of Nebraska - Lincoln

DigitalCommons@University of Nebraska - Lincoln

USDA Forest Service / UNL Faculty Publications U.S. Department of Agriculture: Forest Service --

National Agroforestry Center

2012

\title{
Mountain pine beetle attack alters the chemistry and flammability of lodgepole pine foliage
}

\author{
Wesley G. Page \\ Utah State University \\ Michael J. Jenkins \\ Utah State University, mike.jenkins@usu.edu \\ Justin B. Runyon \\ USDA Forest Service
}

Follow this and additional works at: https://digitalcommons.unl.edu/usdafsfacpub

Part of the Forest Sciences Commons

Page, Wesley G.; Jenkins, Michael J.; and Runyon, Justin B., "Mountain pine beetle attack alters the chemistry and flammability of lodgepole pine foliage" (2012). USDA Forest Service / UNL Faculty Publications. 166.

https://digitalcommons.unl.edu/usdafsfacpub/166

This Article is brought to you for free and open access by the U.S. Department of Agriculture: Forest Service -National Agroforestry Center at DigitalCommons@University of Nebraska - Lincoln. It has been accepted for inclusion in USDA Forest Service / UNL Faculty Publications by an authorized administrator of DigitalCommons@University of Nebraska - Lincoln. 


\title{
Mountain pine beetle attack alters the chemistry and flammability of lodgepole pine foliage
}

\author{
Wesley G. Page, Michael J. Jenkins, and Justin B. Runyon
}

\begin{abstract}
During periods with epidemic mountain pine beetle (Dendroctonus ponderosae Hopkins) populations in lodgepole pine (Pinus contorta Dougl. ex Loud. var. latifolia Engelm.) forests, large amounts of tree foliage are thought to undergo changes in moisture content and chemistry brought about by tree decline and death. However, many of the presumed changes have yet to be quantified. In this study, we quantified and compared fuel moisture, chemistry, and resulting flammability of bark beetle affected foliage in terms of ignitability, combustibility, consumability, and sustainability at a site in far eastern Idaho, USA. Results revealed substantial decreases in moisture content, the proportion of starches and sugars, and crude fat and increases in the proportions of lignin, cellulose, and hemicellulose in foliage of trees attacked in the previous year (yellow foliage) or more than two years previously (red foliage). Increases in emission rates of several terpenes that were correlated with flammability were also detected in yellow foliage. The flammability of fresh yellow and red foliage increased with regard to ignitability and sustainability, with shorter times to ignition, lower temperatures at ignition, and higher heat yields when compared with unattacked green foliage. Our results confirm the overwhelming importance of fuel moisture on flammability and suggest that fuel chemical composition also has significant effects on lodgepole pine foliage flammability.
\end{abstract}

\begin{abstract}
Résumé : Durant les périodes où les populations de dendroctone du pin ponderosa (Dendroctonus ponderosae Hopkins) atteignent des niveaux épidémiques dans les forêts de pin tordu (Pinus contorta Dougl. ex Loud. var. latifolia Engelm.), on croit que la teneur en humidité et les caractéristiques chimiques de grandes quantités de feuillage subissent des changements provoqués par le dépérissement et la mort des arbres. Cependant, plusieurs des changements présumés n'ont toujours pas été quantifiés. Dans cette étude, nous avons quantifié et comparé l'humidité des combustibles, les caractéristiques chimiques et l'inflammabilité du feuillage à la suite de l'attaque du dendroctone en termes d'allumabilité, de combustibilité, de consommabilité et de durabilité dans une station située dans l'extrême est de l'Idaho, aux États-Unis. Les résultats ont révélé qu'il y avait une diminution importante de la teneur en humidité, de la proportion d'amidon et de sucres, de matière grasse brute et une augmentation de la proportion de lignine, de cellulose et d'hémicellulose dans le feuillage des arbres attaqués l'année précédente (le feuillage jaune) ou il y plus de deux ans (le feuillage rouge). L'augmentation du taux d'émission de plusieurs terpènes qui était corrélé avec l'inflammabilité a également été détectée dans le feuillage jaune. L'inflammabilité du feuillage frais jaune ou rouge a augmenté en termes d'allumabilité et de durabilité avec un temps d'allumage plus court, une température d'allumage plus basse et un rendement calorifique plus élevé comparativement au feuillage vert sain. Nos résultats confirment l'importance considérable de l'humidité des combustibles sur l'inflammabilité et indiquent que la composition chimique des combustibles a également des effets significatifs sur l'inflammabilité du feuillage du pin tordu.
\end{abstract}

[Traduit par la Rédaction]

\section{Introduction}

Lodgepole pine (Pinus contorta Dougl. ex Loud. var. latifolia Engelm.) forests in North America have experienced widespread mountain pine beetle (MPB; Coleoptera: Curculionidae; Dendroctonus ponderosae Hopkins) mortality since the 1990s. Dramatic increases in total area affected by the MPB have been observed in the western United States since 2000, with over 3.5 million hectares of mortality in 2009 alone (Man 2010). Although the scale of the recent mortality is unparalleled during the last 100 years, the last two decades have been characterized by a combination of conditions favorable for an outbreak, including warming, drought, and contiguous areas stocked with susceptible trees (Bentz et al.
2010). The severity and scale of the outbreak have caused concern among forest managers, politicians, and the public about the potential impact of the mortality on fire occurrence, severity, and behavior (Rocky Mountain Research Station 2011). Jenkins et al. (2008) reviewed literature on the influence of bark beetles on fuels and fire behavior in three conifer-host systems. Other recent studies have quantified MPB-induced changes to fuels and potential fire behavior in affected forests in Colorado (Klutsch et al. 2009, 2011), Idaho and Utah (Page and Jenkins 2007a, 2007b), and Wyoming (Simard et al. 2011). However, significant uncertainty still remains as to the applicability of the fire modeling systems used in these studies to assess fire behavior potential, particularly crown fire potential, due to unknown changes in

Received 9 February 2012. Accepted 31 May 2012. Published at www.nrcresearchpress.com/cjfr on 31 July 2012.

W.G. Page and M.J. Jenkins. Department of Wildland Resources, Utah State University, 5230 Old Main Hill, Logan, UT 84322, USA.

J.B. Runyon. Rocky Mountain Research Station, USDA Forest Service, 1648 South 7th Avenue, Bozeman, MT 59717, USA.

Corresponding author: Michael J. Jenkins (e-mail: mike.jenkins@usu.edu). 
the moisture content and chemistry of the foliage brought about by tree decline and death.

Conifer forest fuels are composed of varying proportions of lignin, cellulose, hemicellulose, extractives, and minerals (Browning 1963). The proportions can differ by tree species and tissue, with the woody constituents containing high proportions of lignin, cellulose, and hemicellulose and the foliage having more extractive content (Kramer and Kozlowski 1960). The relative amounts of these compounds in forest fuels are known to affect flammability (Shafizadeh et al. 1977; Rundel 1981). Lignin is the primary polymer providing structure to woody fuels. Its high relative molecular mass requires relatively high temperatures for volatilization, producing much of the char residue left after combustion (Shafizadeh 1971). The celluloses and hemicelluloses, found in the cell walls of plants, are the primary source of volatiles in flaming combustion (Shafizadeh 1968). Mineral ash is composed of silica, calcium, magnesium, and potassium and represents the noncombustible portion of plant material. The minerals are usually present in low amounts, though they can influence flammability (Philpot 1970). Extractives are the high energy resins, waxes, oils, and other fatty acids involved in the early phases of combustion due to their low relative molecular masses and ability to volatilize at low temperatures (Philpot and Mutch 1971; Rundel 1981). Terpenes are the main constituents of plant essential oils and resins and include all chemically modified forms such as terpenoids, also known as isoprenoids. They make up the majority of what are known as volatile organic compounds and are classified based on the number of isoprene units in their chemical structure, with monoterpenes having two isoprene units (Goldstein and Galbally 2007). Terpenes have a wide array of uses both ecologically and commercially and are known to play important roles in plant defenses against insect herbivores (Gershenzon and Dudareva 2007). They are also highly flammable both in their pure form and within wildland fuels (Ormeño et al. 2009).

The term flammability has been variously defined, interpreted, and measured using an array of equipment and methodologies (White and Zipperer 2010). Anderson (1970) quantified flammability in terms of three basic components of fire ignition and combustion: ignitability, sustainability, and combustibility. Martin et al. (1994) added the term, consumability, to describe a fourth basic component, the amount of fuel consumed during combustion. There is currently no standard methodology for determining flammability, but several researchers have used these four components to test and classify plants and their parts (Alessio et al. 2008; Ormeño et al. 2009; White and Zipperer 2010). The characteristics that affect plant flammability are relatively well known and can be divided into physical or structural elements and physiological or cellular elements (Rundel 1981). The physiological elements that affect plant flammability are moisture content (Gill et al. 1978), silica-free mineral content (Mutch and Philpot 1970), volatile compounds and ether extractive content (Philpot and Mutch 1971; Susott 1982; Ormeño et al. 2009), cellulose content (Rundel 1981), and phosphorous content (Philpot 1970).

Although substantial progress has been made in recent years in understanding the interactions between bark beetle caused tree morality and subsequent changes in fire behavior, numerous challenges remain. The applicability and accuracy of crown fire behavior models to disturbance-altered fuel complexes remain in question because many were developed based on live healthy crown fuel and do not have the ability to incorporate changes in the physical and chemical properties of altered crown fuel (Jenkins et al. 2012). For example, one of the most widely used crown fire initiation relationships described by Van Wagner (1977) may be affected by changes in the flammability characteristics of foliage because the relationship was based in part on an experimental fire in a live red pine (Pinus resinosa Aiton) plantation in eastern Canada. In a recent critique of the use of crown fire behavior models in simulation studies, Cruz and Alexander (2010) questioned the validity of using Van Wagner's (1977) crown fire initiation model in insect-damaged stands without verifying the need for appropriate adjustments.

The work presented here describes changes to the chemistry and flammability of lodgepole pine foliage when trees have been attacked by the MPB. The specific objectives of the study were $(i)$ to compare the changes in fuel moisture, chemical composition, and flammability of foliage from lodgepole pine trees currently infested by MPB (green infested, GI), infested one year earlier (yellow, Y), and infested more than two years earlier (red, R) with uninfested (green, G) trees, and (ii) to determine the relative importance of fuel moisture and chemical composition, including terpene emissions, on foliage flammability using correlation and regression based analyses.

\section{Methods}

USDA Forest Service Forest Health Monitoring insect and disease aerial detection maps and ground reconnaissance were used to identify potential study areas within the Intermountain Region of the western United States. We selected a study area located near our laboratory in Logan, Utah, that had adequate numbers of uninfested and recently infested lodgepole pine trees. The area chosen was located approximately $5 \mathrm{~km}$ west of Alpine Junction, Wyoming, on the Palisades Ranger District of the Caribou-Targhee National Forest $\left(43^{\circ} 8^{\prime} 14^{\prime \prime} \mathrm{N}, 111^{\circ} 3^{\prime} 44^{\prime \prime} \mathrm{W}\right)$. Within the study area, we selected a sampling site of approximately $1 \mathrm{~km}^{2}$ in size at an elevation of $1768 \mathrm{~m}$ above mean sea level. The site had an average slope of $2 \%$ and was dominated by a mixture of lodgepole pine, Douglas-fir (Pseudotsuga menziesii (Mirbel) Franco), and subalpine fir (Abies lasiocarpa Nutt.), with an average tree density between 3000 and 5000 stems per hectare and a stand basal area of 10 to $20 \mathrm{~m}^{2} \cdot \mathrm{ha}^{-1}$. The habitat type was classified as subalpine fir - common snowberry, and the age of the stand was approximately 100 years. The site has been subject to MPB-caused tree mortality since 2004 (Robertson 2011).

The general study design consisted of the repeated sampling of individual trees over the summer of 2011 during the historically significant portion of the fire season, from July through September. We categorized potential sample trees according to four crown condition classes based on Jenkins (2011): G, green, unattacked but susceptible to attack (i.e., $\geq 20 \mathrm{~cm}$ diameter at breast height, dbh); GI, green, currently infested; Y, yellow, attacked the previous summer; and R, red, more than two years after infestation. We used a combi- 
nation of physical inspection of the tree bole (e.g., pitch tubes, frass) and needle color, similar to Klutsch et al. (2009), to identify time since attack. Specific trees were selected, in order of importance, $(i)$ based on their suitability for repeated field sampling (i.e., presence of branches within reach of equipment), (ii) to minimize between-tree variation (i.e., sample trees had similar diameters and heights), and (iii) to facilitate the logistical needs of sampling (e.g., distance to road or trail).

\section{Field sampling}

Field sampling occurred each week from the beginning of July to the end of September. In total, we sampled 30 trees, $12 \mathrm{G}$ trees, six GI trees, six Y trees, and six R trees; however, only 24 trees were sampled throughout the entire study period. An additional six $G$ trees were sampled only during the month of July as the GI trees were not yet available; these extra $G$ trees were dropped from sampling starting the first week in August. The mean dbh (standard error) of selected G, GI, Y, and R trees were 29.1 (2.15), 30.7 (2.44), 33.8 (4.04), and $32.2 \mathrm{~cm}(1.67 \mathrm{~cm})$, respectively. Due to logistical and time constraints, we sampled 12 trees each week, three trees in each of the four crown condition classes, except during the month of July when the additional $G$ trees were sampled. The remaining 12 trees were sampled the following week. This process was repeated throughout the field season, with each tree (minus the extra six G trees) sampled a total of six times. Sampling occurred on the Monday of each week from the hours of 1000 to 1600 local time. Air temperature and relative humidity were measured with a sling psychrometer before each sampling period. Temperatures ranged from 12.2 to $23.3{ }^{\circ} \mathrm{C}$ and relative humidities ranged from $46 \%$ to $90 \%$. Individual tree sampling consisted of the removal of three subsamples of approximately the $30 \mathrm{~cm}$ apical part of lower branch and foliage material from the lower one-third of each crown and the collection of about $100 \mathrm{~g}$ of litter beneath each tree. Although changes in moisture content and foliage chemical composition are expected at different crown locations within live conifers (White 1954; Hinckley et al. 1978), these changes are relatively minor compared with expected differences among crown condition classes, and crown locations outside of the crown base are not as important in terms of crown fire initiation. Collected samples were placed in separate plastic bags and labeled for transport back to the laboratory. All sampling was completed by $1600 \mathrm{~h}$, after which samples were returned to the laboratory for further processing and analyses.

Volatiles were collected once each month (during the first two weeks) on each sample tree using portable volatile collection systems comprised of automated vacuum pumps enclosed in a waterproof case (Volatile Assay Systems, Rensselaer, New York). For each tree, approximately $70 \mathrm{~cm}$ of the apical part of a lower branch was enclosed in a clear Teflon bag $(50 \mathrm{~cm}$ wide $\times 75 \mathrm{~cm}$ deep; American Durafilm Co., Holliston, Massachusetts) and the air was pulled out through a side port $\left(0.5 \mathrm{~L} \cdot \mathrm{min}^{-1}\right)$ through volatile traps containing $30 \mathrm{mg}$ of the adsorbent HayeSep-Q (Restek, Bellefonte, Pennsylvania). Volatile emissions were collected for 30 min from each tree. Once collections were completed, the enclosed portion of branch and foliage was clipped and placed into a plastic bag for transport back to the laboratory to obtain the fresh mass.

\section{Laboratory analyses}

Once the bagged samples reached the laboratory, they were processed for further analyses. The needles were separated from the branches, and the branches were trimmed to retain material less than $0.64 \mathrm{~cm}$ in diameter because these fuels can contribute to crown fire activity (Call and Albini 1997). The needles were then subdivided by separating current year's needle growth from older needles using visual indicators of color, texture, and location of the previous year's terminal bud. Fuel moisture was the only measured variable on current year's needles, whereas the older needles were used for all other analyses, as they usually make up the majority of tree foliage. To determine fuel moisture content, 15 to $40 \mathrm{~g}$ of each sample were weighed and placed in a forced-air drying oven set at $60{ }^{\circ} \mathrm{C}$ rather than $105^{\circ} \mathrm{C}$, as recommend by Matthews (2010), to dry for $24 \mathrm{~h}$ to minimize the loss of volatiles (Englund and Nussbaum 2000).

During the first two weeks of each month, an additional $\sim 70 \mathrm{~g}$ of the fresh foliage and the volatile traps were shipped to external laboratories for chemical analyses. The foliage samples were shipped to a forage testing laboratory where they were analyzed to determine the chemical composition using the wet chemistry method for the fiber and nonfiber determinations (AgriAnalysis 2012). Acid detergent fiber (ADF) was measured following AOAC (Association of Official Analytical Chemists) standard 973.18 in which the samples were extracted using a quaternary detergent solution (AOAC 1990). Neutral detergent fiber (NDF) was measured using a combination of the ANKOM filter-bag technique (ANKOM Technology 2012) and the amylase procedure (Undersander et al. 2011). Crude fat content was determined using an ANIKOM fat extractor, and ash content was measured following AOAC standard 942.05 by subjecting samples to $600{ }^{\circ} \mathrm{C}$ for $2 \mathrm{~h}$ in a furnace (AOAC 1990; AgriAnalysis 2012). The nonfiber carbohydrates (NFC) represented the remaining fraction of dry matter after subtracting NDF, crude fat, protein, and ash content. NDF includes the hemicelluloses, cellulose, and lignin portions of the foliage. ADF is a subset of NDF and includes the lignin and cellulose portions of the foliage. NFC represents primarily the starches and sugar portion of the foliage. The crude fat characterizes the ether extractable portion of the foliage, which includes compounds such as triglycerides, alcohols, waxes, terpenes, and resins (Barnes et al. 2007).

The volatile collection traps were shipped to the Rocky Mountain Research Station laboratory in Bozeman, Montana, for analysis of volatile emissions, based on methods adapted from Runyon et al. (2008). Volatiles were eluded from traps with $200 \mu \mathrm{L}$ of dichloromethane using $500 \mathrm{ng}$ of $n$-octane and $1000 \mathrm{ng}$ of $n$-nonyl-acetate as internal standards. Samples were analyzed using an Agilent 7890A gas chromatograph (GC) coupled with a 5975C mass spectrometer and separated on a HP-1ms $(30 \mathrm{~m} \times 0.25 \mathrm{~mm}$ inside diameter, $0.25 \mu \mathrm{m}$ film thickness) column; hydrogen was used as the carrier gas. The GC oven was maintained at $35{ }^{\circ} \mathrm{C}$ for $3 \mathrm{~min}$ and then increased by $5{ }^{\circ} \mathrm{C} \cdot \mathrm{min}^{-1}$ to $125^{\circ} \mathrm{C}$, then $25^{\circ} \mathrm{C} \cdot \mathrm{min}^{-1}$ to $250{ }^{\circ} \mathrm{C}$. Quantifications were made relative to internal standards using ChemStation software (Agilent Technologies, 
Wilmington, Delaware), and identifications of compounds were confirmed by comparing retention times and mass spectra with commercial standards. We lacked internal standards for identification of some compounds, which we labeled as unknown terpenes 1 through 6 . All measurements of volatile emissions $\left(\mathrm{ng} \cdot \mathrm{h}^{-1} \cdot \mathrm{g}^{-1}\right)$ were on a fresh mass basis.

\section{Flammability testing}

Flammability testing was accomplished in the laboratory using an epiradiator, adapted to work with a scale, and a bomb calorimeter. The laboratory setup was comprised of a heat source, type $\mathrm{K}$ thermocouple, and pilot ignition source, set over a scale to measure the rate of mass loss (Fig. 1). Mass loss information, as well as temperature, were recorded using a Campbell Scientific CR800 data logger. The heat source consisted of a $500 \mathrm{~W}$ silica epiradiator with a $100 \mathrm{~mm}$ diameter disk producing approximately $6 \mathrm{~W} \cdot \mathrm{cm}^{-2}$ of radiation at the surface. The sample was placed $4 \mathrm{~cm}$ below the epiradiator on top of a stand to protect the scale from excessive heat. A type $\mathrm{K}$ thermocouple probe was set approximately $1.5 \mathrm{~cm}$ above the middle of the sample to record temperature. The pilot ignition source was provided by a Bunsen burner, the center of which was placed $3 \mathrm{~cm}$ above and at the edge of the sample. The pilot flame was $2.5 \mathrm{~cm}$ long with a $1.5 \mathrm{~cm}$ long inner flame core (cf. Dimitrakopoulos and Papaioannou 2001). The individual samples were placed under the middle of the epiradiator in a $7 \times 8 \mathrm{~cm}$ wire mesh holder. The experimental setup was similar to those of other studies that have used an epiradiator for flammability testing of wildland fuels (e.g., Alessio et al. 2008; Ormeño et al. 2009). It is recognized that the heating regime produced by the epiradiator in this study does not replicate the potential heat flux observed in crown fires and that the level of heat flux can affect the influence of fuel properties on flammability, especially moisture content (Fletcher et al. 2007; Fernandes and Cruz 2012). However, the relatively low heat flux levels used in this study are important for determining the influence of fuel properties during the transition from a surface fire to a crown fire. At heat flux levels near this critical transition threshold, differences in the intrinsic fuel properties could potentially have important implications on the likelihood for the onset of crowning. A bomb calorimeter was used to measure the high heat of combustion of oven-dried foliage samples. All calorimeter samples were tested following ASTM D standard 1989-96, with corrections for the fuse wire, aqueous sulfuric acid, and nitric acid formed during the bomb reaction.

Flammability testing with the bomb calorimeter started during the first week in July, whereas the epiradiator-based testing began during the first week in August. One sample from each tree was tested with the bomb calorimeter each week, whereas two samples per tree, fresh and oven-dried, were tested with the epiradiator each week. Fresh foliage samples were tested first during each sampling period followed by oven-dried foliage. The epiradiator samples were prepared for testing by placing the needles evenly across the entire holder surface to a depth of approximately $1.5 \mathrm{~cm}$. Due to the significant variation in foliage moisture content, the fresh samples had different initial masses; however, the dry foliage samples were all tested at a mass of $3.0 \mathrm{~g} \pm 0.1 \mathrm{~g}$. Once a sample was prepared, it was placed on top of the stand and the epiradiator was lowered into position. The data logger was set to collect mass and temperature continuously throughout the experiment every $0.1 \mathrm{~s}$, with a date and time stamp for each recorded observation. The time of initiation of flaming and the end of flaming were recorded to the nearest second. Samples were allowed to smolder until the rate of mass loss was negligible. This process was repeated for each sample until all tests were completed.

\section{Measures of flammability}

Ignitability, the amount of time that it takes a material to ignite given an external heat source and (or) the minimum temperature or heat flux required for ignition, was assessed using time to ignition and temperature at ignition (Anderson 1970). Time to ignition was measured from when the temperature of the thermocouple reached $60{ }^{\circ} \mathrm{C}$ until the first appearance of flame, rounded to the nearest second. The temperature at ignition was recorded at the initiation of flaming. Temperatures at ignition reported here do not represent the actual fuel temperature obtained at ignition because the thermocouple was $1.5 \mathrm{~cm}$ above the material. Combustibility, which is a measure of how rapid or intensely a fire burns, was the maximum temperature obtained during each test and the maximum rate of temperature increase during flaming combustion $\left({ }^{\circ} \mathrm{C} \cdot \mathrm{s}^{-1}\right)$ (Anderson 1970; White and Zipperer 2010). Consumability, or the quantity and completeness of combustion, was judged using time profiles of mass loss, as well as the maximum rate of mass loss $\left(\mathrm{g} \cdot \mathrm{s}^{-1}\right)$ (Martin et al. 1994; White and Zipperer 2010). To smooth the mass loss rate profiles, the $5 \mathrm{~s}$ running mean was calculated and used to determine the maximum mass loss rate. Sustainability, the amount of time that materials will combust with or without a heat source, was recorded as the duration of flaming (in seconds) and the high heat of combustion $\left(\mathrm{kJ}^{\mathrm{k}} \mathrm{kg}^{-1}\right)$. The high heat of combustion is the total amount of heat released by a fuel when it is completely consumed to water and carbon dioxide without reductions for moisture, radiation, or incomplete combustion. A low heat of combustion or net heat of combustion, which incorporates a reduction based on the latent heat absorbed when the water of reaction is vaporized, is usually used in fire behavior applications (Byram 1959; Alexander 1982). However, when comparing the potential heat available under field conditions, a further correction is used to account for the heat required to evaporate the moisture in the fuel, termed heat yield (Van Wagner 1972). In this study, we report the high heat of combustion, but we refer to heat yield when discussing potential energy release among crown condition classes.

\section{Statistical analysis}

Repeated measures analysis of variance was used to compare mean responses between crown condition classes for each of the response variables. The fuel moisture and flammability data were grouped by the two-week intervals for which we had data for each of the trees measured. This grouping resulted in comparisons of six different two-week time periods for the fuel moisture and bomb calorimeter data and four two-week periods for the epiradiator-based flammability testing. The chemical analysis data, both volatile emissions and foliage chemistry, were grouped by the month in which they were collected, for a total of three unique time 
Fig. 1. Experimental setup for laboratory flammability testing: (a) type K thermocouple probe; $(b) 500 \mathrm{~W}$ silica epiradiator; $(c)$ pilot ignition source; $(d)$ sample holder; and $(e)$ data logger connected to scale and thermocouple.

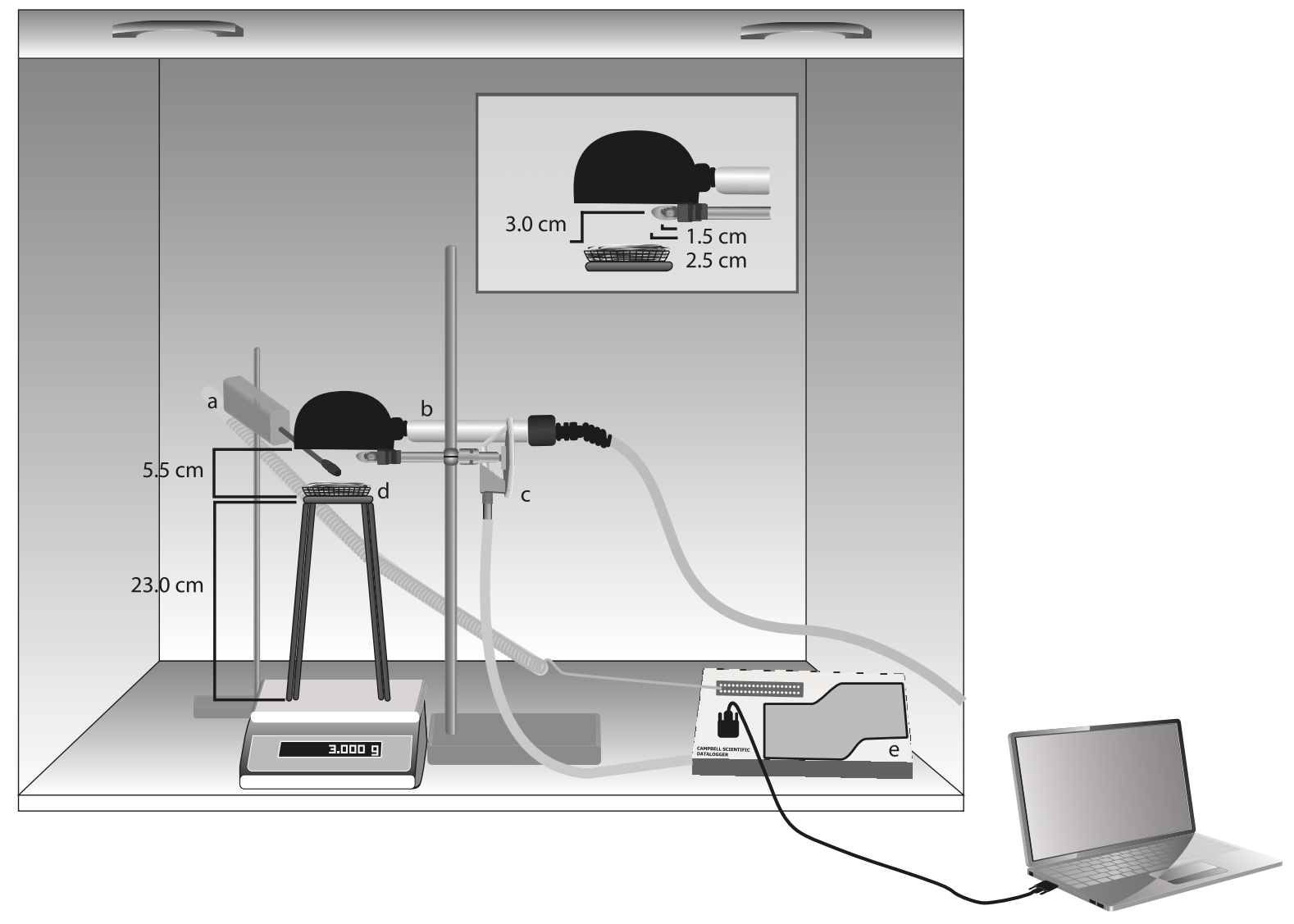

periods. The three subsamples of fuel moisture collected from each tree were averaged by tree for analysis. Squareroot and natural logarithm transformations were used where needed to meet assumptions of normality and equal variances. Post hoc means comparisons using the Tukey-Kramer method to control the experiment-wise error rate were used when a significant difference among crown conditions classes was identified (Zar 1999). When the assumptions of normality and equal variance were not satisfied with transformations, the nonparametric Kruskal-Wallis test (Zar 1999) was used to compare ranks followed by multiple comparison tests among crown condition classes using the technique described by Elliott and Hynan (2011). Pearson's correlation coefficients $(r)$ were used to identify linear relationships between the flammability parameters and the various chemical attributes. Multiple linear regression analysis with stepwise selection was also used to evaluate linear relationships between time to ignition and the chemical attributes for fresh foliage to account for the influence of fuel moisture. SAS software (version 9.3, SAS Institute, Inc. 2010) was used for all statistical analysis. Significance for all tests was identified using $\alpha=0.05$.

\section{Results}

\section{Fuel moisture}

Foliar moisture content varied substantially by crown condition class (Fig. 2). The moisture content of new foliage for $\mathrm{G}$ trees was well above $200 \%$ of oven-dried mass during the early part of July and dropped to near $150 \%$ by the end of September; new foliage moisture content of GI trees followed a similar trend. Older foliage moisture content was the same for $\mathrm{G}$ and $\mathrm{GI}$ trees $(P=0.2970)$ when averaged over all sampling periods, with means of $113 \%$ and $115 \%$, respectively (Table 1). The moisture content of $\mathrm{G}$ foliage was nearly constant over time, with a peak during early August of $125 \%$. During early July, the foliage from Y trees had a mean moisture content of $43 \%$, which was less than the G mean of $99 \%$ $(P<0.0001)$ and greater than the $\mathrm{R}$ mean of $10 \%(P=$ $0.0019)$. However, by the end of July, the moisture content of $\mathrm{Y}$ and $\mathrm{R}$ foliage did not differ $(P=0.3533)$ and stayed the same throughout the remaining sampling periods. The mean foliar moisture content of $113 \%$ for the $G$ trees, averaged over all sampling periods, was greater than the mean foliar moisture content of both the Y (24\%; approximately five times greater) and R (13\%; approximately nine times greater) trees $(P<0.0001)$ (Table 1). Moisture content of litter and $\mathrm{R}$ foliage was the same throughout all sampling periods $(P=$ 0.6531). The moisture content of twig fuel was similar to that of the foliage (Fig. 3). The G and GI twig moisture contents did not differ $(P=0.8749)$ and were greater than the $\mathrm{Y}$ and $\mathrm{R}$ twig moisture contents $(P<0.0001)$. Mean litter and $\mathrm{R}$ twig moisture contents were the same for all sampling periods $(P=0.8890)$. The peak in moisture content of mean litter, $\mathrm{R}$ foliage, and twigs during early August is attributed to a high relative humidity $(90 \%)$ during sampling. The minimum mean foliar moisture content recorded for $\mathrm{G}$ trees was 99\%, which occurred during early July (Table 1). The mini- 
Fig. 2. Mean foliar moisture content for new foliage and old foliage and the mean litter moisture content for all sampling periods (JulySeptember (E, early; L, late)), with associated standard error bars, for each of the crown condition classes (G, green; GI, green infested; $\mathrm{Y}$, yellow; R, red).

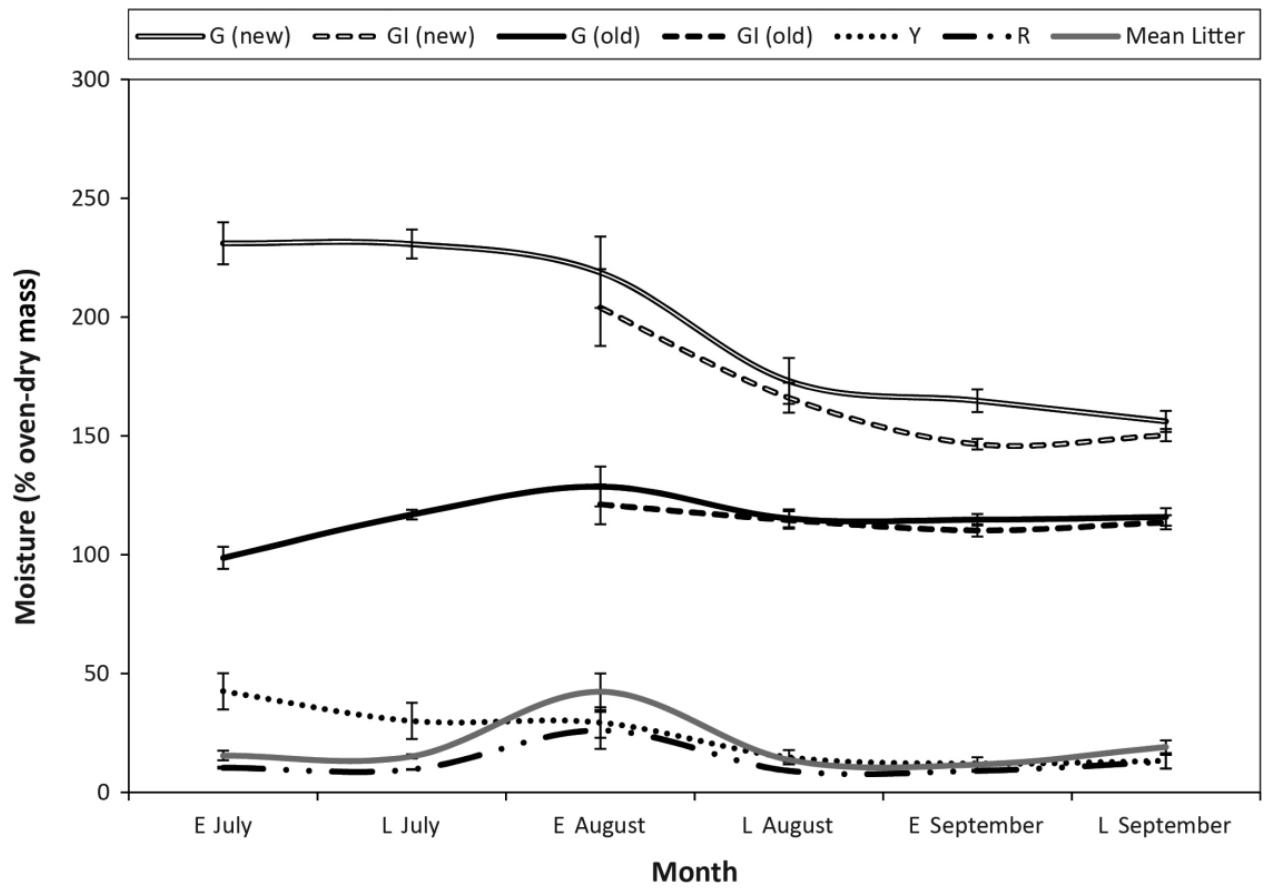

Table 1. Mean ( \pm standard error $(\mathrm{SE})$ ) percentage of oven-dried fuel moisture content, averaged over all sampling periods (July-September), for old foliage and twigs $<0.64 \mathrm{~cm}$ in diameter and the minimum mean values (Min.) recorded for each crown condition class (G, green; GI, green infested; Y, yellow; R, red).

\begin{tabular}{|c|c|c|c|c|c|c|c|c|}
\hline \multirow[b]{3}{*}{ Type } & \multicolumn{8}{|c|}{ Crown condition } \\
\hline & \multicolumn{2}{|l|}{$\mathrm{G}$} & \multicolumn{2}{|l|}{ GI } & \multicolumn{2}{|l|}{$\mathrm{Y}$} & \multicolumn{2}{|l|}{$\mathrm{R}$} \\
\hline & Mean $\pm \mathrm{SE}$ & Min. & Mean \pm SE & Min. & Mean $\pm \mathrm{SE}$ & Min. & Mean \pm SE & Min. \\
\hline Old foliage (\%) & $113 \pm 2 a$ & 99 & $115 \pm 2 \mathrm{a}$ & 110 & $24 \pm 3 b$ & 12 & $13 \pm 2 b$ & 9 \\
\hline Twig $<0.64 \mathrm{~cm}(\%)$ & $107 \pm 3 a$ & 99 & $100 \pm 5 a$ & 91 & $19 \pm 3 b$ & 9 & $15 \pm 3 b$ & 9 \\
\hline
\end{tabular}

Note: Means followed by a different letter within a row are significantly different $(\alpha=0.05)$.

mum moisture contents for $\mathrm{Y}$ and $\mathrm{R}$ foliage, which both occurred in September, were $12 \%$ and $9 \%$, respectively.

\section{Chemical analyses}

Chemical analysis of the foliage in each of the four crown condition classes revealed significant differences in NDF, ADF, NFC, crude fat, and mineral content (Table 2). For all compounds, comparison of the mean levels of G and GI foliage and of $\mathrm{Y}$ and $\mathrm{R}$ foliage were the same $(P>0.05)$. The mean level of NDF for $\mathrm{G}$ foliage across all three months, $43 \%$, was less than the mean level of both $\mathrm{Y}$ foliage, $67 \%$ $(P<0.0001)$, and $\mathrm{R}$ foliage, 69\% $(P<0.0001)$. Mean ADF levels for $Y$ and $R$ foliage were also greater than $G$ foliage over all sampling periods. The mean proportion of NFC in $\mathrm{G}$ foliage was $38 \%$, which was greater than the mean levels for $\mathrm{Y}$ foliage, $18 \%(P<0.0001)$, and $\mathrm{R}$ foliage, $14 \%(P<$ $0.0001)$. The proportion of phosphorus in $\mathrm{R}$ foliage was higher than in $\mathrm{G}$ foliage when averaged over all sampling periods $(P=0.0441)$ and during the month of July $(P=$ 0.0335). Levels of magnesium were also different, with higher proportions in GI foliage than in $\mathrm{Y}$ foliage $(P=$ 0.0371 ) when averaged over all sampling periods. The pro- portion of crude fat was significantly greater in $\mathrm{G}$ foliage than in $\mathrm{Y}$ foliage $(P=0.0008)$ and $\mathrm{R}$ foliage $(P=0.0098)$, with mean levels of $8.7 \%, 5.9 \%$, and $6.5 \%$, respectively. The most significant changes over time occurred in the chemical makeup of $\mathrm{Y}$ foliage. The mean proportion of ADF increased in $\mathrm{Y}$ foliage each month of sampling but was only significant when comparing July with September $(P=0.0003)$. The proportion of crude fat also decreased in $\mathrm{Y}$ foliage from July to September $(P=0.0481)$.

Analysis of volatile emissions revealed large variation in emission rates within crown classes and significant differences both in mean total and individual emission rates (Fig. 4). In total, 16 different terpenes were identified, with nine of the compounds significantly correlated with flammability (see results below). The mean total volatile emissions averaged over all sampling periods for $\mathrm{Y}$ foliage was greater than the mean emission rates for $\mathrm{R}$ foliage $(P=0.0079)$. No other significant differences were detected. However, several of the individual terpene emissions were greater in $\mathrm{Y}$ foliage than in the other crown condition classes when averaged over all sampling periods (Fig. 4). Unknown terpenes 2 and $6, p$ cymene, $E$ - $\beta$-ocimene, and $\beta$-myrcene had higher emission 
Fig. 3. Mean twig ( $<0.64 \mathrm{~cm}$ in diameter) moisture content for each of the crown condition classes (G, green; GI, green infested; Y, yellow; $\mathrm{R}$, red) and the mean litter moisture content for all sampling periods (July-September (E, early; L, late)), with associated standard error bars.

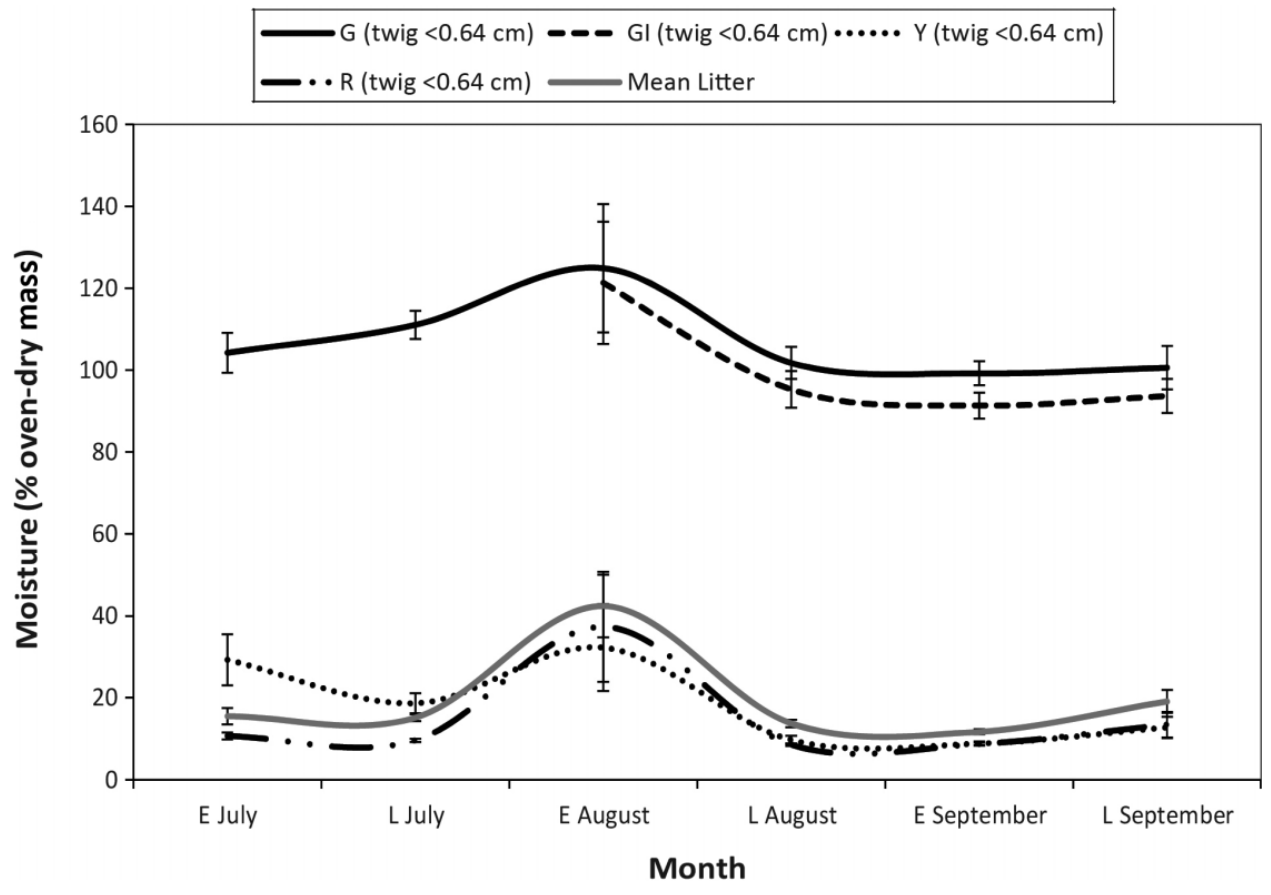

rates in $\mathrm{Y}$ foliage than in $\mathrm{R}$ foliage. The emission rates of unknown terpene $2, E$ - $\beta$-ocimene, $\beta$-myrcene, $\alpha$-pinene, $p$-cymene, tricyclene, and camphene were higher in $\mathrm{Y}$ foliage than in $\mathrm{G}$ foliage.

\section{Ignitability}

Time to ignition for fresh foliage differed among crown condition classes (Fig. 5A). Mean time to ignition for $\mathrm{G}$ and GI foliage was 216 and 232 s, respectively, which was longer than the mean times for $\mathrm{Y}$ and $\mathrm{R}$ foliage, 79 and $66 \mathrm{~s}$, respectively $(P<0.0001)$. Mean time to ignition for dry foliage among G (28 s), Y (34 s), and R foliage (32 s) $(P=0.6733)$ was not significantly different. Multiple linear regression analysis indicated that fuel moisture and collection date were the most significant predictors of time to ignition for fresh foliage, which together explained $77 \%$ of the total variation. Fuel moisture alone accounted for $65 \%$ of the total variation in time to ignition of fresh foliage. After accounting for the effects of fuel moisture, the proportion of protein $(P=$ $0.009)$ and potassium $(P=0.0157)$ had significant negative relationships with time to ignition, which increased the proportion of total variation explained to $82 \%$ (Table 3 ). Individual correlation analysis of the volatile terpene compounds with time to ignition for fresh foliage indicated that two compounds had significant negative correlations (Table 4): $E-\beta$ ocimene and tricyclene. The strongest relationship was with $E$ - $\beta$-ocimene, with an $r$ of -0.366 .

The differences between temperatures recorded at ignition for fresh foliage were similar to the results for time to ignition (Fig. 5C). The temperatures between $\mathrm{G}$ and GI foliage $(P=0.3519)$ and between $\mathrm{Y}$ and $\mathrm{R}$ foliage $(P=0.9936)$ were not different. The mean temperature at ignition for $G$ foliage of $279{ }^{\circ} \mathrm{C}$ was higher than the mean temperatures for $\mathrm{Y}$ of $195^{\circ} \mathrm{C}(P<0.0001)$ and for $\mathrm{R}$ of $198{ }^{\circ} \mathrm{C}(P=0.0001)$ fresh foliage. Mean temperature at ignition of dry foliage for
$\mathrm{G}$ trees of $131{ }^{\circ} \mathrm{C}$ was lower than the mean temperatures for $\mathrm{Y}$ of $159{ }^{\circ} \mathrm{C}(P=0.0024)$ and for $\mathrm{R}$ foliage of $150{ }^{\circ} \mathrm{C}(P=$ 0.0228) (Fig. 6B). Correlations of individual terpene compounds with temperature at ignition for fresh foliage indicated that $E$ - $\beta$-ocimene had a negative relationship, with a $r$ of -0.304 (Table 4). Correlations of dry foliage with the chemical compounds indicated that NDF, ADF, NFC, and crude fat had significant linear relationships with temperature at ignition (Table 5). NDF and ADF had positive relationships, whereas NFC and crude fat content had negative relationships with temperature at ignition.

\section{Combustibility}

The mean maximum temperature obtained during the flammability testing of fresh foliage was highest for GI foliage $\left(460{ }^{\circ} \mathrm{C}\right)$, which was greater than $\mathrm{Y}\left(413{ }^{\circ} \mathrm{C}\right)(P=$ $0.0201)$ and $\mathrm{R}\left(410{ }^{\circ} \mathrm{C}\right)(P=0.0122)$ foliage (Fig. 5D). Mean maximum temperatures among G, Y, and R fresh foliage were not different $(P=0.2292)$. Mean maximum temperatures of dry foliage were not significantly different among crown condition classes. Comparisons of the maximum rate of temperature increase among crown condition classes indicated no significant differences for fresh or dry foliage (Fig. 5F).

\section{Consumability}

Comparisons of the time series of mass loss rates of dry foliage for each of the crown condition classes suggested similarity both when the mass loss rates were averaged over all sample periods and during individual sampling periods. The mean level of mass loss for dry $G$ foliage was higher than those for the other crown condition classes, but when the $95 \%$ confidence intervals were included, the mass loss rates overlapped substantially among all crown classes. 
Table 2. Mean proportion of foliage chemical composition for each sampling period across all crown condition classes (G, green; GI, green infested; Y, yellow; R, red).

\begin{tabular}{|c|c|c|c|c|c|}
\hline & Crown condition & July & August & September & Overall \\
\hline \multirow[t]{4}{*}{ Protein (\%) } & $\mathrm{G}$ & $7.8 \pm 0.33 a$ & $7.8 \pm 0.32 \mathrm{a}$ & $8.1 \pm 0.48 \mathrm{a}$ & $7.9 \pm 0.21 \mathrm{a}$ \\
\hline & GI & $\mathrm{n} / \mathrm{a}$ & $7 \pm 0.34 \mathrm{a}$ & $7.5 \pm 0.37 \mathrm{a}$ & $7.2 \pm 0.25 \mathrm{a}$ \\
\hline & $\mathrm{Y}$ & $6.9 \pm 0.22 \mathrm{a}$ & $6.9 \pm 0.34 \mathrm{a}$ & $7 \pm 0.15 a$ & $6.9 \pm 0.13 \mathrm{a}$ \\
\hline & $\mathrm{R}$ & $8.1 \pm 0.37 \mathrm{a}$ & $7.8 \pm 0.52 \mathrm{a}$ & $7.9 \pm 0.41 \mathrm{a}$ & $7.9 \pm 0.24 \mathrm{a}$ \\
\hline \multirow[t]{4}{*}{ Acid detergent fiber (\%) } & G & $35.8 \pm 0.46 \mathrm{a}$ & $35.5 \pm 0.57 \mathrm{a}$ & $34.7 \pm 0.91 \mathrm{a}$ & $35.4 \pm 0.35 \mathrm{a}$ \\
\hline & GI & $\mathrm{n} / \mathrm{a}$ & $37.6 \pm 1.45 \mathrm{a}$ & $36.3 \pm 0.92 \mathrm{a}$ & $36.9 \pm 0.84 a$ \\
\hline & $\mathrm{Y}$ & $48 \pm 1.8 \mathrm{~b}$ & $51.7 \pm 1.98 \mathrm{~b}$ & $54.7 \pm 1.41 b$ & $51.5 \pm 4.91 b$ \\
\hline & $\mathrm{R}$ & $52.4 \pm 1.48 b$ & $52.5 \pm 1.19 b$ & $54.1 \pm 1.1 \mathrm{~b}$ & $53.0 \pm 3.02 b$ \\
\hline \multirow[t]{4}{*}{ Neutral detergent fiber $(\%)$} & G & $44.2 \pm 1.53 \mathrm{a}$ & $42 \pm 0.59 \mathrm{a}$ & $41.7 \pm 1.1 \mathrm{a}$ & $43 \pm 0.84 a$ \\
\hline & GI & $\mathrm{n} / \mathrm{a}$ & $47 \pm 3.47 \mathrm{a}$ & $42.3 \pm 1.58 \mathrm{a}$ & $44.6 \pm 1.95 \mathrm{a}$ \\
\hline & $\mathrm{Y}$ & $62.8 \pm 4.16 b$ & $70.7 \pm 1.08 \mathrm{~b}$ & $66.5 \pm 1.25 b$ & $66.7 \pm 1.6 \mathrm{~b}$ \\
\hline & $\mathrm{R}$ & $70.7 \pm 0.91 b$ & $69.6 \pm 1.42 b$ & $67.2 \pm 1.34 \mathrm{~b}$ & $69.2 \pm 0.76 b$ \\
\hline \multirow[t]{4}{*}{ Nonfiber carbohydrates (\%) } & $\mathrm{G}$ & $36.2 \pm 1.25 \mathrm{a}$ & $40 \pm 0.66 \mathrm{a}$ & $40.3 \pm 0.75 a$ & $38.2 \pm 0.77 \mathrm{a}$ \\
\hline & GI & $\mathrm{n} / \mathrm{a}$ & $34.1 \pm 3.32 \mathrm{a}$ & $39.2 \pm 1.24 \mathrm{a}$ & $36.6 \pm 1.86 a$ \\
\hline & $\mathrm{Y}$ & $21.1 \pm 4.21 b$ & $14.4 \pm 0.62 b$ & $19.1 \pm 1.37 b$ & $18.2 \pm 1.56 b$ \\
\hline & $\mathrm{R}$ & $12.4 \pm 0.76 b$ & $13.1 \pm 1.61 b$ & $15.8 \pm 1.46 \mathrm{~b}$ & $13.8 \pm 0.8 b$ \\
\hline \multirow[t]{4}{*}{ Calcium (\%) } & $\mathrm{G}$ & $0.43 \pm 0.04 a$ & $0.39 \pm 0.05 a$ & $0.34 \pm 0.02 \mathrm{a}$ & $0.4 \pm 0.02 \mathrm{a}$ \\
\hline & GI & $\mathrm{n} / \mathrm{a}$ & $0.58 \pm 0.11 \mathrm{a}$ & $0.44 \pm 0.05 a$ & $0.51 \pm 0.06 a$ \\
\hline & $\mathrm{Y}$ & $0.43 \pm 0.05 a$ & $0.31 \pm 0.04 a$ & $0.36 \pm 0.04 a$ & $0.37 \pm 0.03 a$ \\
\hline & $\mathrm{R}$ & $0.34 \pm 0.03 a$ & $0.38 \pm 0.05 a$ & $0.4 \pm 0.03 a$ & $0.37 \pm 0.02 \mathrm{a}$ \\
\hline \multirow[t]{4}{*}{ Phosphorus (\%) } & $\mathrm{G}$ & $0.1 \pm 0.01 \mathrm{a}$ & $0.08 \pm 0.01 \mathrm{a}$ & $0.1 \pm 0.01 \mathrm{a}$ & $0.1 \pm 0.005 a$ \\
\hline & GI & $\mathrm{n} / \mathrm{a}$ & $0.09 \pm 0.01 \mathrm{a}$ & $0.1 \pm 01 \mathrm{a}$ & $0.1 \pm 0.005 \mathrm{ab}$ \\
\hline & $\mathrm{Y}$ & $0.12 \pm 0.01 \mathrm{ab}$ & $0.11 \pm 0.02 \mathrm{a}$ & $0.1 \pm 0.01 \mathrm{a}$ & $0.11 \pm 0.01 \mathrm{ab}$ \\
\hline & $\mathrm{R}$ & $0.14 \pm 0.01 b$ & $0.1 \pm 0.01 \mathrm{a}$ & $0.11 \pm 0.01 \mathrm{a}$ & $0.12 \pm 0.01 b$ \\
\hline \multirow[t]{4}{*}{ Potassium (\%) } & G & $0.44 \pm 0.03 a$ & $0.46 \pm 0.07 \mathrm{a}$ & $0.38 \pm 0.05 \mathrm{a}$ & $0.43 \pm 0.03 a$ \\
\hline & GI & $\mathrm{n} / \mathrm{a}$ & $0.46 \pm 0.12 \mathrm{a}$ & $0.45 \pm 0.11 \mathrm{a}$ & $0.46 \pm 0.08 \mathrm{a}$ \\
\hline & $\mathrm{Y}$ & $0.49 \pm 0.07 a$ & $0.45 \pm 0.06 a$ & $0.32 \pm 0.03 a$ & $0.42 \pm 0.04 a$ \\
\hline & $\mathrm{R}$ & $0.49 \pm 0.05 a$ & $0.5 \pm 0.06 \mathrm{a}$ & $0.36 \pm 0.03 \mathrm{a}$ & $0.45 \pm 0.03 \mathrm{a}$ \\
\hline \multirow[t]{4}{*}{ Magnesium (\%) } & $\mathrm{G}$ & $0.15 \pm 0.01 \mathrm{a}$ & $0.15 \pm 0.01 \mathrm{ab}$ & $0.13 \pm 0.01 \mathrm{a}$ & $0.14 \pm 0.01 \mathrm{ab}$ \\
\hline & GI & $\mathrm{n} / \mathrm{a}$ & $0.2 \pm 0.02 \mathrm{a}$ & $0.15 \pm 0.02 \mathrm{a}$ & $0.18 \pm 0.02 \mathrm{a}$ \\
\hline & $\mathrm{Y}$ & $0.15 \pm 0.01 \mathrm{a}$ & $0.12 \pm 0.01 b$ & $0.12 \pm 0.01 \mathrm{a}$ & $0.13 \pm 0.01 b$ \\
\hline & $\mathrm{R}$ & $0.14 \pm 0.01 \mathrm{a}$ & $0.16 \pm 0.02 \mathrm{ab}$ & $0.14 \pm 0.004 a$ & $0.15 \pm 0.01 \mathrm{ab}$ \\
\hline \multirow[t]{4}{*}{ Crude fat $(\%)$} & $\mathrm{G}$ & $9.5 \pm 0.42 \mathrm{a}$ & $8 \pm 0.51 \mathrm{ab}$ & $7.8 \pm 0.46 \mathrm{a}$ & $8.7 \pm 0.31 \mathrm{a}$ \\
\hline & GI & $\mathrm{n} / \mathrm{a}$ & $9.1 \pm 0.65 \mathrm{a}$ & $8.6 \pm 0.2 \mathrm{a}$ & $8.8 \pm 0.33 \mathrm{a}$ \\
\hline & $\mathrm{Y}$ & $6.6 \pm 0.74 b$ & $5.8 \pm 0.71 \mathrm{~b}$ & $5.2 \pm 0.63 b$ & $5.9 \pm 0.4 b$ \\
\hline & $\mathrm{R}$ & $6.4 \pm 0.27 b$ & $6.6 \pm 0.28 \mathrm{ab}$ & $6.5 \pm 0.28 \mathrm{ab}$ & $6.5 \pm 0.15 b$ \\
\hline \multirow[t]{4}{*}{ Total ash (\%) } & $\mathrm{G}$ & $2.3 \pm 0.11 \mathrm{a}$ & $2.2 \pm 0.13 \mathrm{a}$ & $2.2 \pm 0.06 \mathrm{a}$ & $2.2 \pm 0.06 \mathrm{a}$ \\
\hline & GI & $\mathrm{n} / \mathrm{a}$ & $2.9 \pm 0.26 \mathrm{a}$ & $2.5 \pm 0.12 \mathrm{a}$ & $2.7 \pm 0.15 a$ \\
\hline & $\mathrm{Y}$ & $2.5 \pm 0.21 \mathrm{a}$ & $2.1 \pm 0.14 \mathrm{a}$ & $2.2 \pm 0.11 \mathrm{a}$ & $2.2 \pm 0.1 \mathrm{a}$ \\
\hline & $\mathrm{R}$ & $2.4 \pm 0.27 \mathrm{a}$ & $2.9 \pm 0.48 \mathrm{a}$ & $2.6 \pm 0.19 \mathrm{a}$ & $2.6 \pm 0.19 \mathrm{a}$ \\
\hline
\end{tabular}

Note: Values are mean \pm standard error. All values are percent dry mass. Means followed by a different letter within a column are significantly different $(\alpha=0.05)$.

The mean maximum rates of mass loss obtained from the flammability testing with fresh foliage did not differ among crown condition classes (Fig. 5E). Correlations of emission rates of total and individual terpene compounds with maximum rate of mass loss for fresh foliage indicated that there were significant positive linear relationships (Table 4). The compounds $\alpha$-pinene, $\beta$-pinene, $\beta$-myrcene, $E$ - $\beta$-ocimene, $p$ cymene, camphene, unknown terpenes 1,2 , and 6 , and total emissions had significant positive relationships with maximum rate of mass loss. The strongest relationship was with unknown terpene 2, with a $r$ of 0.357. Maximum rates of mass loss among crown condition classes with dry foliage were not significantly different.

\section{Sustainability}

Measurements of the duration of flaming for fresh foliage indicated that there were no significant differences among crown condition classes (Fig. 5B). For dry foliage, the mean duration of flaming for GI foliage of $64 \mathrm{~s}$ was longer than the means for $\mathrm{Y}$ foliage of $49 \mathrm{~s}(P=0.0010)$ and for $\mathrm{R}$ foliage of 55 s $(P=0.0352)$ (Fig. 6A). The mean duration of flaming for $\mathrm{G}$ foliage of $56 \mathrm{~s}$ was not different from those for GI $(P=$ $0.1353)$, Y $(P=0.2007)$, or R $(P=0.9809)$ foliage. Correlations of duration of flaming with the chemical attributes for dry foliage indicated that several of the chemicals had significant linear relationships (Table 5). NDF and ADF had negative $r$ values, -0.344 and -0.471 , respectively, with duration 
Fig. 4. Mean volatile terpene emission rates separated by compounds that were significantly correlated with flammability by crown condition class (G, green; GI, green infested; Y, yellow; R, red) for all months (July-September), with associated standard error bars; letters on bars indicate significant differences within sampling period. The individual terpene compounds are stacked according to the order in the legend. Comparisons of individual terpenes are for mean emission rates across all sampling periods, and significance is indicated in the legend in parentheses after each compound (condition class in bold followed by corresponding significance letter(s)). The crown condition classes in the legend are arranged from highest to lowest mean values, and bars and terpene names with a different letter have means that are significantly different at the $\alpha=0.05$ level.

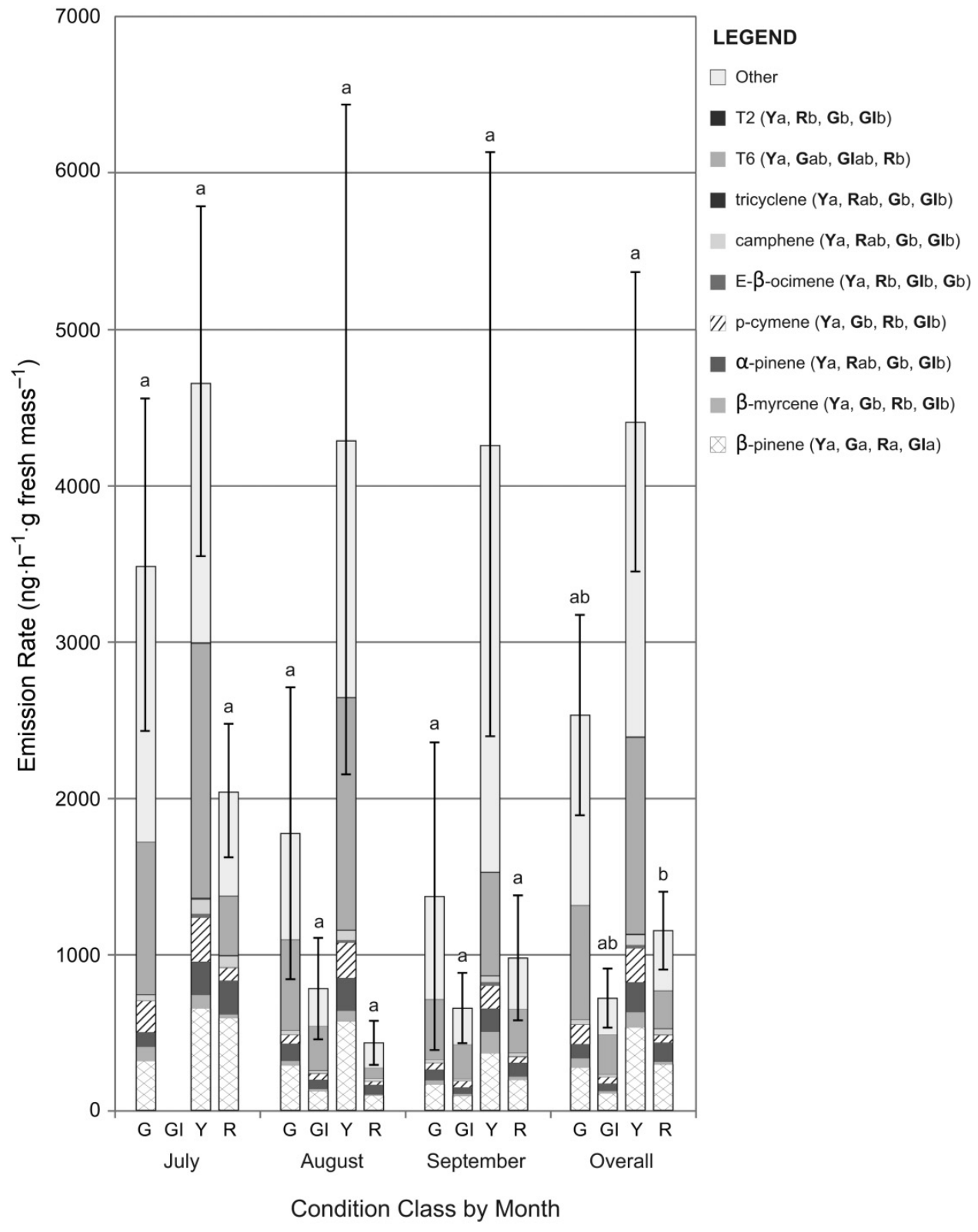

of flaming. Calcium, magnesium, and crude fat had significant positive linear relationships with the duration of flaming, with $r$ values of $0.311,0.430$, and 0.536 , respectively.

Differences in high heat of combustion among crown condition classes were found (Table 6). G foliage had higher heat of combustion than $\mathrm{Y}(P=0.0091)$ and $\mathrm{R}(P=0.0136)$ foliage averaged over all sampling periods. High heats of combustion between $\mathrm{G}$ and $\mathrm{GI}$ foliage $(P=0.7814)$ and $\mathrm{R}$ and $\mathrm{Y}$ foliage $(P=0.9881)$ were not different. Measured heats of combustion did not change over time for GI, Y, or R foli- age. However, the heat of combustion for $\mathrm{G}$ foliage dropped from early July to late August $(P=0.0277)$ but increased to early July levels by late September $(P=0.9763)$. When the overall mean high heats of combustion were adjusted for the latent heat of water during combustion and for moisture content, the mean heat yield of $\mathrm{Y}$ foliage $\left(18610 \mathrm{KJ} \cdot \mathrm{kg}^{-1}\right)$ and $\mathrm{R}$ foliage (18 $900 \mathrm{KJ} \cdot \mathrm{kg}^{-1}$ ) was higher than the heat yield of $\mathrm{G}$ foliage $\left(17070 \mathrm{KJ} \cdot \mathrm{kg}^{-1}\right)$. There were several significant correlations of high heat of combustion with the chemical attributes (Table 6). NDF and ADF had negative relationships with 
Fig. 5. Box-and-whisker plots of the flammability test results for fresh foliage, including (A) time to ignition, (B) duration of flaming, (C) temperature at ignition, (D) maximum temperature, (E) maximum (Max.) rate of mass loss, and (F) maximum (Max.) rate of temperature change for each of the crown condition classes (G, green; GI, green infested; Y, yellow; R, red), averaged over all sampling periods. The diamond represents the mean, the horizontal line is the median, the lower and upper box ends represent the lower and upper quartiles, and the whiskers are the minimum and maximum values, respectively. Bars with a different letter have means that are significantly different at the $\alpha=$ 0.05 level. n.s., nonsignificant.
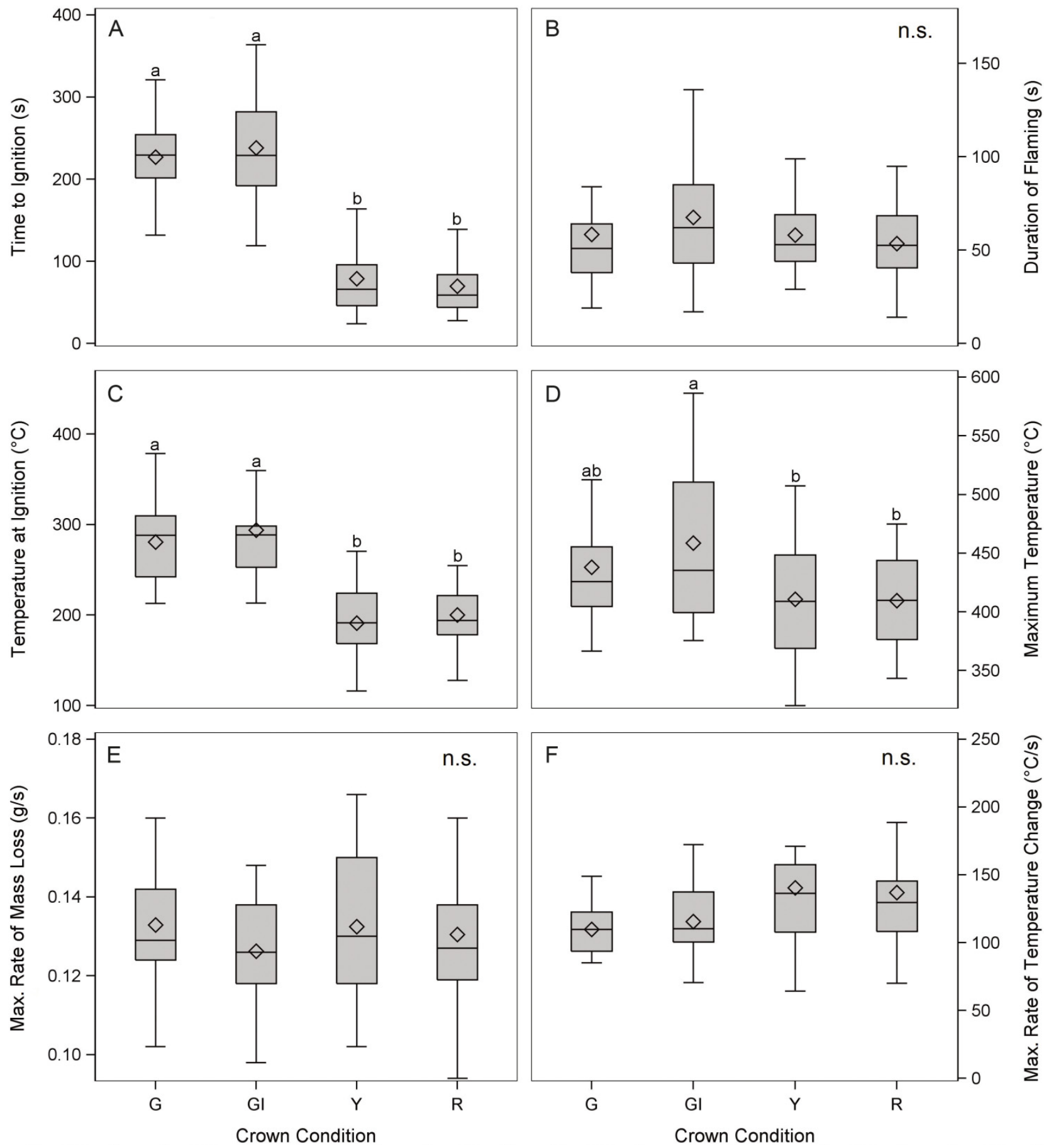

heat of combustion, with $r$ values of -0.459 and -0.451 , respectively. Proportions of protein, NFC, and crude fat had significant positive relationships with the high heats of combustion. The strongest relationship was with the proportion of crude fat, with a $r$ of 0.520 . A summary of all results is presented in Fig. 7.

\section{Discussion}

Our results indicated that MPB attack significantly alters the chemistry and flammability of lodgepole pine foliage. The moisture content and chemical makeup of foliage from the most recently attacked trees (GI) did not substantially dif- 
Table 3. Parameter estimates and goodness-of-fit statistics for the best linear regression model obtained using stepwise selection regressing time to ignition of fresh foliage on the chemical composition variables.

\begin{tabular}{lclc}
\hline Variable & Coefficient & Standard error & $P$ value \\
\hline Intercept & 9.24 & 2.42 & 0.0001 \\
Collection date & 0.64 & 0.13 & $<0.0001$ \\
Moisture content & 7.01 & 0.51 & $<0.0001$ \\
Protein (\%) & -0.74 & 0.272 & 0.009 \\
Potassium (\%) & -3.99 & 1.59 & 0.0157 \\
$R^{2}$ & 0.823 & & \\
Adjusted $R^{2}$ & 0.806 & & \\
Mean square error & 3.1 & & \\
\hline
\end{tabular}

Note: The response variable is the square root of the time to ignition, $n=48$.

Table 4. Pearson's correlation coefficients $(r)$ and associated $P$ values among the flammability parameters time to ignition, temperature at ignition, and maximum rate of mass loss with individual terpene compound emission rates $\left(\mathrm{ng} \cdot \mathrm{h}^{-1} \cdot \mathrm{g}\right.$ fresh mass $\left.^{-1}\right)$ for fresh foliage.

\begin{tabular}{|c|c|c|c|c|c|c|}
\hline & \multicolumn{2}{|c|}{ Time to ignition* } & \multicolumn{2}{|c|}{ Temperature at ignition* } & \multicolumn{2}{|c|}{ Maximum rate of mass loss } \\
\hline & $r$ & $P$ value & $r$ & $P$ value & $r$ & $P$ value \\
\hline$\alpha$-Pinene $^{\dagger}$ & -0.227 & 0.1215 & -0.148 & 0.3157 & 0.325 & 0.0257 \\
\hline$\beta$-Pinene ${ }^{\dagger}$ & -0.104 & 0.4815 & -0.047 & 0.7515 & 0.305 & 0.0371 \\
\hline$\beta$-Myrcene ${ }^{\dagger}$ & -0.110 & 0.4554 & -0.114 & 0.4403 & 0.301 & 0.0398 \\
\hline$E-\beta$-Ocimene ${ }^{\dagger}$ & -0.366 & 0.0106 & -0.304 & 0.0354 & 0.302 & 0.0391 \\
\hline$p$-cymene ${ }^{\dagger}$ & -0.177 & 0.2296 & -0.158 & 0.2840 & 0.295 & 0.0443 \\
\hline Camphene $^{\dagger}$ & -0.275 & 0.0590 & -0.181 & 0.2171 & 0.311 & 0.0331 \\
\hline Tricyclene $^{\dagger}$ & -0.285 & 0.0500 & -0.192 & 0.1914 & 0.319 & 0.0289 \\
\hline Unknown $\mathrm{T}^{\dagger}$ & -0.222 & 0.1286 & -0.199 & 0.1760 & 0.357 & 0.0138 \\
\hline Unknown $\mathrm{T}^{\dagger}$ & -0.049 & 0.7440 & -0.028 & 0.8517 & 0.345 & 0.0187 \\
\hline Total $^{\dagger}$ & -0.163 & 0.2697 & -0.139 & 0.3473 & 0.309 & 0.0345 \\
\hline
\end{tabular}

fer from $\mathrm{G}$ foliage. It has been suggested by Jolly et al. (2012) that the foliar moisture content of recently attacked trees may decrease during the summer of attack. Beetle flight on our site began during the last week in June and was not complete until mid- to late July. Other sites at lower latitudes and elevations may experience beetle flight sooner, possibly affecting the potential for significant decreases in moisture content during the summer of attack. As a result of the similarities between G and GI foliage, the measured flammability parameters for ignitability, combustibility, consumability, and sustainability were equivalent.

The substantial differences in moisture content detected among $\mathrm{G}$, Y, and $\mathrm{R}$ foliage had clear implications on flammability. The bulk of moisture loss in the transition from the GI to Y crown condition class occurred during the winter and spring months, outside the main fire season when we sampled. This is similar to the results of Gibson and Negrón (2009), who reported substantial decreases in foliar moisture during the early spring and summer following the summer of attack. This decrease in moisture content substantially altered the ignitability and sustainability flammability parameters of foliage. Mean times to ignition of fresh $\mathrm{Y}$ and $\mathrm{R}$ foliage were more than 2.5 times shorter than for $G$ foliage. Likewise, the mean temperature at ignition for $\mathrm{Y}$ and $\mathrm{R}$ foliage was almost 1.5 times lower than $\mathrm{G}$ foliage. The shorter times to ignition suggest that stands composed of significant proportions of $\mathrm{Y}$ and $\mathrm{R}$ foliage may have lower transition thresholds for crown fire development, as proposed by Knight (1987) and Jenkins et al. (2008), both diurnally and seasonally compared with healthy stands. The measured high heats of combustion for $\mathrm{G}$ and GI foliage were within the range reported by others for live foliage (Hough 1969; Williamson and Agee 2002). However, by adjusting the high heat of combustion to heat yield, we found that the heat yields of $\mathrm{Y}$ and $\mathrm{R}$ foliage were higher than the heat yield of $\mathrm{G}$ foliage, suggesting that once crown fire activity begins, there may be higher fire intensities in stands with $\mathrm{Y}$ and $\mathrm{R}$ trees than similar healthy stands.

The increase in the structural compounds of foliage (NDF and $\mathrm{ADF}$ ) and the decrease in the starches and sugars (NFC) and crude fat in $\mathrm{Y}$ and $\mathrm{R}$ foliage had significant influences on flammability, particularly ignitability and sustainability. The increase in temperature at ignition of dry $\mathrm{Y}$ and $\mathrm{R}$ foliage compared with $\mathrm{G}$ foliage may be the result of increasing portions of lignin, cellulose, and hemicellulose and decreasing proportion of crude fat content. Lignin, which has a relatively high relative molecular mass, is known to be more thermally stable and therefore less volatile than cellulose or carbohydrates (Kitao and Watanabe 1967; Shafizadeh 1971). In contrast, carbohydrates, and especially ether extractable 
Fig. 6. Box-and-whisker plots of the flammability test results for dry foliage, including (A) duration of flaming and (B) temperature at ignition for each of the crown condition classes (G, green; GI, green infested; Y, yellow; R, red), averaged over all sampling periods. The diamond represents the mean, the horizontal line is the median, the lower and upper box ends represent the lower and upper quartiles, and the whiskers are the minimum and maximum values, respectively. Bars with a different letter have means that are significantly different at the $\alpha=$ 0.05 level. $\bigcirc$, outliers.
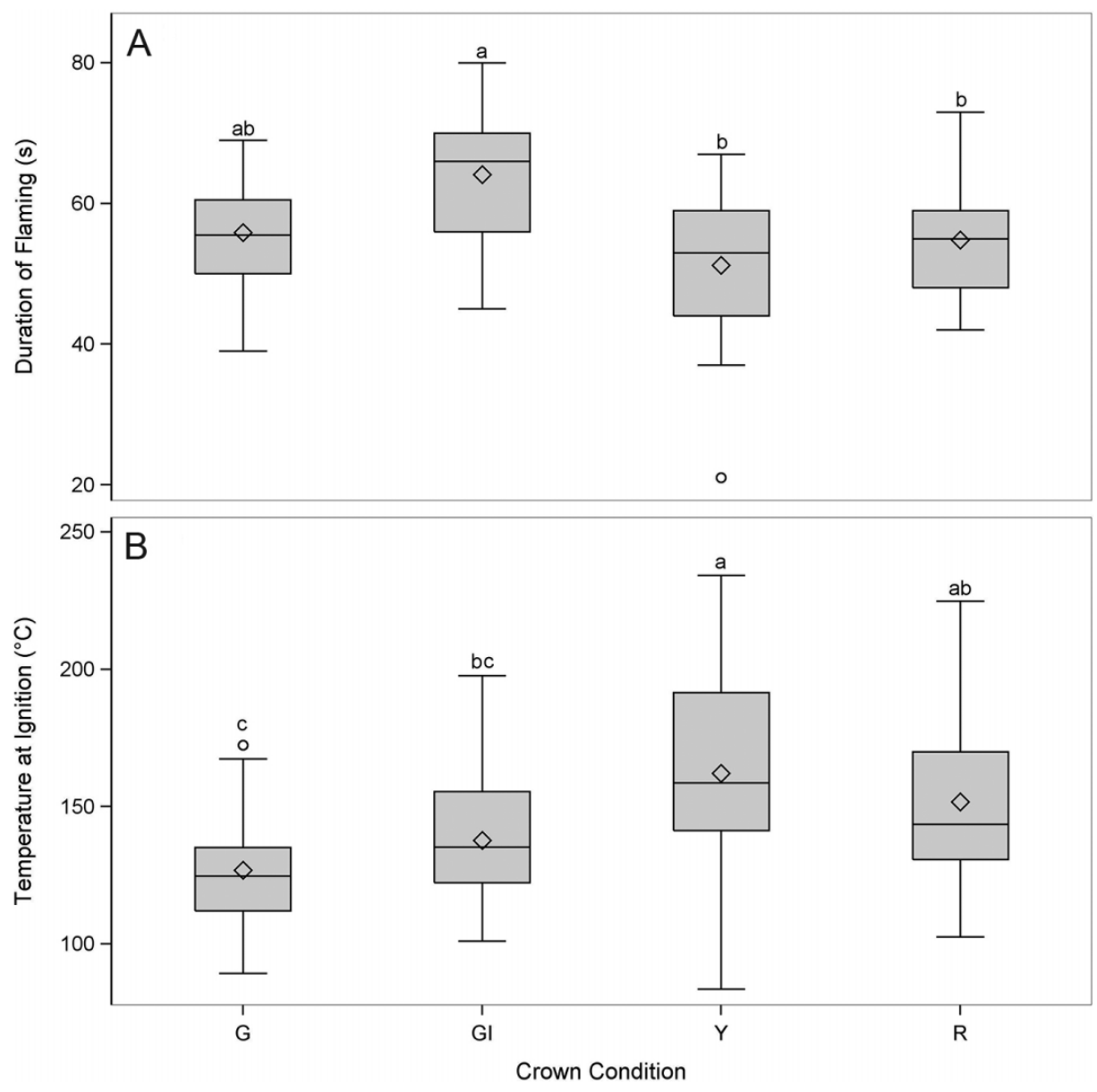

Table 5. Pearson's correlation coefficients $(r)$ and associated $P$ values for duration of flaming, temperature at ignition, and high heat of combustion with the chemical composition groups for dry foliage.

\begin{tabular}{|c|c|c|c|c|c|c|}
\hline & \multicolumn{2}{|c|}{ Duration of flaming } & \multicolumn{2}{|c|}{ Temperature at ignition } & \multicolumn{2}{|c|}{ High heat of combustion } \\
\hline & $r$ & $P$ value & $r$ & $P$ value & $r$ & $P$ value \\
\hline Protein & 0.098 & 0.5381 & -0.216 & 0.1694 & 0.270 & 0.023 \\
\hline Acid detergent fiber & -0.471 & 0.0016 & 0.488 & 0.001 & -0.451 & $<0.0001$ \\
\hline Neutral detergent fiber & -0.344 & 0.0258 & 0.507 & 0.0006 & -0.459 & $<0.0001$ \\
\hline Nonfiber carbohydrates & 0.300 & 0.0536 & -0.485 & 0.0011 & 0.413 & 0.0003 \\
\hline $\mathrm{Ca}$ & 0.311 & 0.0451 & -0.119 & 0.4513 & -0.034 & 0.7765 \\
\hline $\mathrm{P}$ & -0.141 & 0.3714 & 0.293 & 0.0596 & 0.001 & 0.9962 \\
\hline $\mathrm{Mg}$ & 0.430 & 0.0045 & -0.081 & 0.6117 & 0.019 & 0.873 \\
\hline Crude fat & 0.536 & 0.0003 & -0.317 & 0.0405 & 0.520 & $<0.0001$ \\
\hline
\end{tabular}

Note: Significant correlations are presented in bold; $n=48$.

compounds (crude fat), have low relative molecular mass and are known to be relatively more volatile and flammable (Shafizadeh et al. 1977; Susott 1980). These changes in foliar chemistry indicate that the inherent ignitability of $\mathrm{Y}$ and $\mathrm{R}$ foliage is lower than that of $\mathrm{G}$ foliage, but our results confirm that the effect of fuel moisture overwhelmed these apparent decreases in ignitability.
The duration of flaming of dry foliage for all crown condition classes was negatively related to the proportions of lignin, cellulose, and hemicellulose but positively related to the proportions of calcium, magnesium, and crude fat. Again, it appears that the high relative molecular mass of the structural compounds of lignin and cellulose reduced the ability of the fuel to sustain flaming combustion, whereas the low relative 
molecular mass and high energy compounds in crude fat extended the period of flaming. The high heats of combustion also had positive linear relationships with crude fat content and the proportion of starches and sugars and negative relationships with the proportions of lignin, cellulose, and hemicellulose. The importance of crude fat content on heat of combustion has been demonstrated by others (Philpot 1969; Philpot and Mutch 1971). However, the negative relationship between the proportion of lignin and cellulose with high heat of combustion appears contrary to the results of White (1987), who found increasing high heats of combustion with increasing lignin content. Determining the nature of the discrepancy is difficult because our measure of lignin (ADF) is confounded with cellulose; thus we were unable to make a direct comparison between high heat of combustion and lignin content to ascertain the reason for the observed drop in heat of combustion.

The results from the volatile terpene measurements indicated significant changes in both total and individual terpene emission rates among $\mathrm{Y}, \mathrm{R}$, and $\mathrm{G}$ foliage. The mean total emission rate of volatiles in $\mathrm{Y}$ foliage was consistently higher during each month of sampling, but due to high variability, the only significant increase detected was between the mean emission rate for $\mathrm{Y}$ foliage and the mean rate for $\mathrm{R}$ foliage. However, several of the individual terpenes related to flammability had higher emission rates in $\mathrm{Y}$ foliage compared with $\mathrm{G}$ foliage. Both of the terpenes identified as negatively correlated with time to ignition and temperature at ignition were emitted at higher rates in $\mathrm{Y}$ foliage than in $\mathrm{G}$ foliage. Likewise, all but two of the nine compounds positively correlated with the maximum rate of mass loss were emitted at higher levels in $Y$ foliage than in $G$ foliage. Terpenes have previously been shown to be an important predictor of flammability for some wildland fuels (Owens et al. 1998; Ormeño et al. 2009) but not for others (Bunting et al. 1983; Alessio et al. 2008). Our results imply that the higher emission rates of some of the terpenes in $\mathrm{Y}$ foliage may have contributed to the increased ignitability observed in $\mathrm{Y}$ versus $\mathrm{G}$ foliage, although the strongest relationship observed was still relatively weak $(r=-0.366)$ compared with the effect of fuel moisture. The cause for the increase in volatile emissions in Y foliage may be related to the decomposition, breakdown, and drying of plant material. The mobilization of water through drying likely supported terpene transport from within the needle to the surface, which, when followed by evaporation, may have produced increased emission rates (Banerjee 2001).

\section{Conclusion}

The foliage of lodgepole pine trees recently affected by MPB undergoes significant changes in moisture status and chemical composition over the course of tree decline and death. Beginning during the first summer following attack, the flammability of infested tree foliage significantly increases and remains high throughout the red crown condition class stage. The most prominent flammability characteristics enhanced in recently infested foliage are ignitability and sustainability, with beetle-affected foliage igniting more readily than healthy foliage and having more potential net energy under field conditions to sustain and promote fireline intensity. The primary factor increasing flammability is decreased moisture content, which overwhelms the inherent decreases 


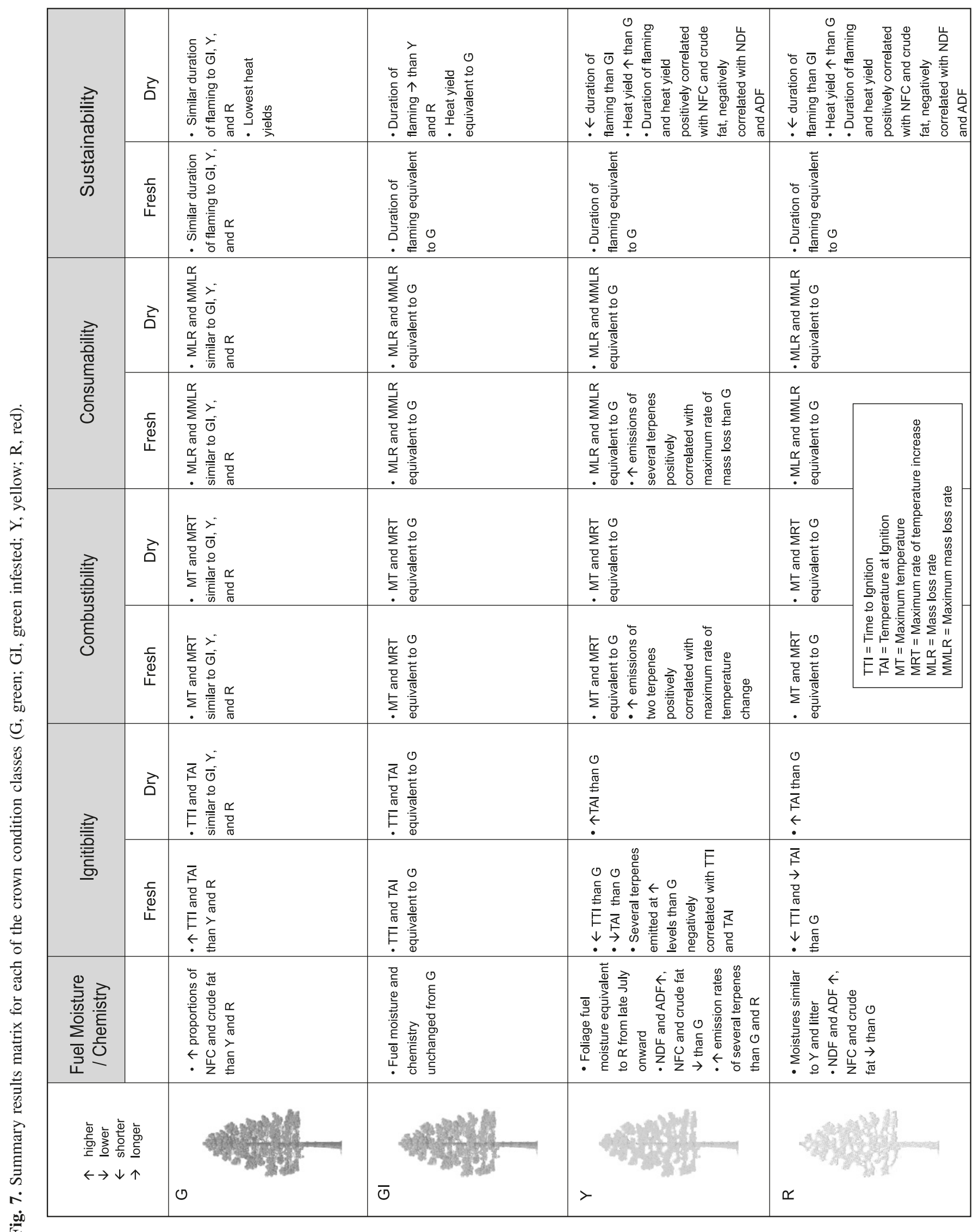

Published by NRC Research Press 
in flammability of recently affected foliage caused by decreases in starches, sugars, and crude fat and increases in lignin, cellulose, and hemicellulose. Considerable quantities of volatile terpenes are present in dead and dying foliage, with trees attacked one year prior $(\mathrm{Y})$ having higher emission rates of those terpenes that promote increased flammability. Although not described here, physical changes in foliage at the individual needle scale were observed that could influence flammability. Observations of $\mathrm{Y}$ and $\mathrm{R}$ needle foliage compared with $\mathrm{G}$ foliage clearly suggest structural differences in the surface area to volume ratio of the needles. Cross sections of individual $\mathrm{G}$ needles of lodgepole pine are best described as cylinders, whereas $\mathrm{R}$ foliage has a flattened, concave structure resembling a blade of grass. The work of Lopushinsky (1970) and Brown (1970) showed differences in the surface area to volume ratio between fully turgid lodgepole pine needles $\left(46.1 \cdot \mathrm{cm}^{-1}\right.$; Lopushinsky 1970) and air-dried lodgepole pine needles $\left(64.7 \cdot \mathrm{cm}^{-1}\right.$; Brown 1970), suggesting enhanced heat transfer to dried-out needles.

Although the period of increased flammability may be relatively short for individual trees (i.e., less than five years), mortality generally occurs over a period of several years within an individual stand, and therefore all stages (G, Y, and R) may occur together for long periods of time. During this window of time, fire managers and firefighters should be aware of the possibility of increased potential for crown fire initiation in affected stands and the prospect for rapid changes in fire behavior as fires move in and out of beetleaffected areas. Future research should focus on documenting wildfire behavior in beetle-affected stands to verify the enhanced flammability predicted here and to gain a better understanding of applicability of current empirical and physics-based models of fire behavior.

\section{Acknowledgments}

Funding for this project was provided by Joint Fire Science Program Project 11-1-4-16. The comments of M.E. Alexander, B.J. Bentz, E.W. Evans, E.G. Hebertson, M.R. Kuhns, and two anonymous reviewers were appreciated. The authors thank C. Stam for help with fieldwork, W. Lindquist for assistance with graphics, and L. Teng at Utah State University's BioEnergy Center for lab equipment support. This research was supported by the Utah Agricultural Experiment Station, Utah State University, and approved as journal paper number 8408 .

\section{References}

AgriAnalysis. 2012. Wet chemistry analysis [online]. Available from http://www.agrianalysis.com [accessed 6 April 2012].

Alessio, G.A., Peñuelas, J., Llusià, J., Ogaya, R., Estiarte, M., and De Lillis, M. 2008. Influence of water and terpenes on flammability in some dominant Mediterranean species. Int. J. Wildland Fire, 17(2): 274-286. doi:10.1071/WF07038.

Alexander, M.E. 1982. Calculating and interpreting forest fire intensities. Can. J. Bot. 60(4): 349-357. doi:10.1139/b82-048.

Anderson, H.E. 1970. Forest fuel ignitibility. Fire Technol. 6(4): 312319. doi:10.1007/BF02588932.

ANKOM Technology. 2012. Neutral detergent fiber in feeds filter bag technique. Available from http://www.ankom.com/media/documents/Method_6_NDF_4013011_A200\%2cA200I.pdf [accessed 9 April 2012].
Association of Official Analytical Chemists. 1990. Official methods of analysis of the Association of Official Analytical Chemists. 15th ed. Association of Official Analytical Chemists, Washington, D.C.

Banerjee, S. 2001. Mechanisms of terpene release during sawdust and flake drying. Holzforschung, 55(4): 413-416. doi:10.1515/HF. 2001.068.

Barnes, R.F., Nelson, C.J., Moore, K.J., and Collins, M. 2007. Forages, the science of grassland agriculture. 6th ed. Blackwell Publishing, Ames, Iowa.

Bentz, B.J., Régnière, J., Fettig, C.J., Hansen, E.M., Hayes, J.L., Hicke, J.A., Kelsey, R.G., Negrón, J.F., and Seybold, S.J. 2010. Climate change and bark beetles of the western United States and Canada: direct and indirect effects. Bioscience, 60(8): 602-613. doi:10.1525/bio.2010.60.8.6.

Brown, J.K. 1970. Ratios of surface area to volume for common fine fuels. For. Sci. 16(1): 101-105.

Browning, B.L. 1963. The chemistry of wood. Interscience (Wiley), New York.

Bunting, S.C., Wright, H.A., and Wallace, W.H. 1983. Seasonal variation in the ignition time of redberry juniper in West Texas. J. Range Manage. 36(2): 169-171. doi:10.2307/3898155.

Byram, G.M. 1959. Combustion of forest fuels. In Forest fire: control and use. Edited by K.P. Davis. McGraw-Hill, New York. pp. 61-89.

Call, P.T., and Albini, F.A. 1997. Aerial and surface fuel consumption in crown fires. Int. J. Wildland Fire, 7(3): 259-264. doi:10.1071/ WF9970259.

Cruz, M.G., and Alexander, M.E. 2010. Assessing crown fire potential in coniferous forests of western North America: a critique of current approaches and recent simulation studies. Int. J. Wildland Fire, 19(4): 377-398. doi:10.1071/WF08132.

Dimitrakopoulos, A.P., and Papaioannou, K.K. 2001. Flammability assessment of Mediterranean forest fuels. Fire Technol. 37(2): 143-152. doi:10.1023/A:1011641601076.

Elliott, A.C., and Hynan, L.S. 2011. A SAS macro implementation of a multiple comparison post hoc test for a Kruskal-Wallis analysis. Comput. Methods Programs Biomed. 102(1): 75-80. doi:10.1016/ j.cmpb.2010.11.002. PMID:21146248.

Englund, F., and Nussbaum, R.M. 2000. Monoterpenes in Scots pine and Norway spruce and their emission during kiln drying. Holzforschung, 54(5): 449-456. doi:10.1515/HF.2000.075.

Fernandes, P.M., and Cruz, M.G. 2012. Plant flammability experiments offer limited insight into vegetation - fire dynamics interactions. New Phytol. 194(3): 606-609. doi:10.1111/j.14698137.2012.04065.x. PMID:22288940.

Fletcher, T.H., Pickett, B.M., Smith, S.G., Spittle, G.S., Woodhouse, M.M., Haake, E., and Weise, D.R. 2007. Effects of moisture on ignition behavior of moist California chaparral and Utah leaves. Combust. Sci. Technol. 179(6): 1183-1203. doi:10.1080/ 00102200601015574.

Gershenzon, J., and Dudareva, N. 2007. The function of terpene natural products in the natural world. Nat. Chem. Biol. 3(7): 408414. doi:10.1038/nchembio.2007.5. PMID:17576428.

Gibson, K., and Negrón, J.F. 2009. Fire and bark beetle interactions. In The Western Bark Beetle Research Group: A Unique Collaboration with Forest Health Protection, Portland, Oregon, 23-28 October 2007. Edited by J.L. Hayes and J.E. Lundquist. USDA Forest Service, Pacific Northwest Research Station, Portland, Oregon, Gen. Tech. Rep. PNW-GTR-784. pp. 51-69.

Gill, A.M., Trollope, W.S.W., and MacArthur, D.A. 1978. Role of moisture in the flammability of natural fuels in the laboratory. Aust. For. Res. 8: 199-208.

Goldstein, A.H., and Galbally, I.E. 2007. Known and unexplored organic constituents in the Earth's atmosphere. Environ. Sci. Technol. 41(5): 1514-1521. doi:10.1021/es072476p. PMID:17396635. 
Hinckley, T.M., Lassoie, J.P., and Running, S.W. 1978. Temporal and spatial variations in the water status of forest trees. For. Sci. Mon. 20 24(3): 1-72.

Hough, W.A. 1969. Caloric value of some forest fuels of the southern United States. USDA Forest Service, Southeastern Forest Experiment Station, Asheville, North Carolina, Res. Note SE-120.

Jenkins, M.J. 2011. Fuel and fire behavior in high-elevation fiveneedle pines affected by mountain pine beetle. In The Future of High-Elevation Five-Needle White Pines in Western North America: Proceedings of the High Five Symposium, Missoula, Montana, 28-30 June 2010. Edited by R.E. Keane, D.F. Tomback, M.P. Murray, and C.M. Smith. USDA Forest Service, Rocky Mountain Research Station, Fort Collins, Colorado, Proceedings RMRS-P-63. pp. 198-205. Available from http://www.fs.fed.us/ rm/pubs/rmrs_p063.html [accessed 23 November 2011].

Jenkins, M.J., Hebertson, E.G., Page, W.G., and Jorgensen, C.A. 2008. Bark beetles, fuels, fires and implications for forest management in the Intermountain West. For. Ecol. Manage. 254 (1): 16-34. doi:10.1016/j.foreco.2007.09.045.

Jenkins, M.J., Page, W.G., Hebertson, E.G., and Alexander, M.E. 2012. Fuels and fire behavior dynamics in bark beetle-attacked forests in Western North America and implications for fire management. For. Ecol. Manage. 275: 23-34. doi:10.1016/j. foreco.2012.02.036.

Jolly, W.M., Parsons, R.A., Hadlow, A.M., Cohn, G., McAllister, S., Popp, J.B., Hubbard, R.M., and Negrón, J.F. 2012. Relationships between moisture, chemistry, and ignition of Pinus contorta needles during the early stages of mountain pine beetle attack. For. Ecol. Manage. 269: 52-59. doi:10.1016/j.foreco.2011.12.022.

Kitao, K., and Watanabe, Y. 1967. Pyrolysis gas chromatography of lignin. Zairyo, 16(169): 844-847. doi:10.2472/jsms.16.844.

Klutsch, J.G., Negrón, J.F., Costello, S.L., Rhoades, C.C., West, D.R., Popp, J., and Caissie, R. 2009. Stand characteristics and downed woody debris accumulations associated with a mountain pine beetle (Dendroctonus ponderosae Hopkins) outbreak in Colorado. For. Ecol. Manage. 258(5): 641-649. doi:10.1016/j. foreco.2009.04.034.

Klutsch, J.G., Battaglia, M.A., West, D.R., Costello, S.L., and Negrón, J.F. 2011. Evaluating potential fire behavior in lodgepole pine-dominated forests after a mountain pine beetle epidemic in north-central Colorado. West. J. Appl. For. 26(3): 101-109.

Knight, D.H. 1987. Parasites, lightning and the vegetation mosaic in wilderness landscapes. In Landscape heterogeneity and disturbance. Edited by M.G. Turner. Springer-Verlag, New York. pp. 59-83.

Kramer, P.J., and Kozlowski, T.T. 1960. Fats, oils, terpenes, and related substances. In Physiology of trees. McGraw-Hill, New York. pp. 140-158.

Lopushinsky, W. 1970. Relationship of needle surface area to needle volume in ponderosa pine and lodgepole pine. USDA Forest Service, Pacific Northwest Forest and Range Experiment Station, Portland, Oregon, Res. Note PNW-126.

Man, G. 2010. Major forest insect and disease conditions in the United States: 2009 update [online]. USDA Forest Service FS-952. Available from http://www.fs.fed.us/foresthealth/publications/ ConditionsReport_2009.pdf [accessed 20 July 2012].

Martin, R.E., Gordon, D.A., Gutierrez, M.E., Lee, D.S., Molina, D.M., Schroeder, R.A., Sapsis, D.B., Stephens, S.L., and Chambers, M. 1994. Assessing the flammability of domestic and wildland vegetation. In Proceedings of the 12th Conference on Fire and Forest Meteorology, Jekyll Island, Georgia, 26-28 October 1993. Society of American Foresters, Bethesda, Maryland. pp. 130-137.

Matthews, S. 2010. Effect of drying temperature on fuel moisture content measurements. Int. J. Wildland Fire, 19(6): 800-802. doi:10.1071/WF08188.

Mutch, R.W., and Philpot, C.W. 1970. Relation of silica content to flammability in grasses. For. Sci. 16: 64-65.

Ormeño, E., Cespedes, B., Sanchez, I., Velasco-garcia, A., Moreno, J., Fernandez, C., and Baldy, V. 2009. The relationship between terpenes and flammability of leaf litter. For. Ecol. Manage. 257(2): 471-482. doi:10.1016/j.foreco.2008.09.019.

Owens, M.K., Lin, C.D., Taylor, C.A., Jr., and Whisenant, S.G. 1998. Seasonal patterns of plant flammability and monoterpenoid content in Juniperus ashei. J. Chem. Ecol. 24(12): 2115-2129. doi:10.1023/A:1020793811615.

Page, W.G., and Jenkins, M.J. 2007a. Mountain pine beetle induced changes to selected lodgepole pine fuel complexes within the Intermountain Region. For. Sci. 53(4): 507-518.

Page, W.G., and Jenkins, M.J. 2007b. Predicted fire behavior in selected mountain pine beetle-infested lodgepole pine. For. Sci. 53(6): 662-674.

Philpot, C.W. 1969. Seasonal changes in heat content and ether extractive content of chamise. USDA Forest Service, Intermountain Forest and Range Experiment Station, Ogden, Utah, Res. Pap. INT-61.

Philpot, C.W. 1970. Influence of mineral content on the pyrolysis of plant material. For. Sci. 16(4): 461-471.

Philpot, C.W., and Mutch, R.W. 1971. The seasonal trends in moisture content, ether extractives, and energy of ponderosa pine and Douglas-fir needles. USDA For. Serv. Res. Pap. INT-102.

Robertson, J.L. 2011. Hoffman area mountain pine beetle infested tree removal project: analysis based on existing conditions 2010 . USDA For. Serv. Silvicultural Prescription, Caribou-Targhee National Forest, Palisades Ranger District, Idaho Falls, Idaho.

Rocky Mountain Research Station. 2011. Review of the Forest Service response: the bark beetle outbreak in northern Colorado and southern Wyoming [online]. USDA Forest Service, Rocky Mountain Region and Rocky Mountain Research Station. Available from http://www.fs.fed.us/rmrs/docs/home/bark-beetle.pdf [accessed 8 December 2011].

Rundel, P.W. 1981. Structural and chemical components of flammability. In Proceedings of the Conference on Fire Regimes and Ecosystem Properties. Edited by H.A. Mooney, T.M. Bonnicksen, N.L. Christensen, J.E. Lotan, and W.E. Reiners. USDA Forest Service, Washington, D.C., Gen. Tech. Rep. WO-26. pp. 183-207.

Runyon, J.B., Mescher, M.C., and De Moraes, C.M. 2008. Parasitism by Cuscuta pentagona attenuates host plant defenses against insect herbivores. Plant Physiol. 146(3): 987-995. doi:10.1104/pp.107. 112219. PMID: 18165323.

SAS Institute, Inc. 2010. Version 9.3 of the SAS System for Windows. SAS Institute Inc., Cary, North Carolina.

Shafizadeh, F. 1968. Pyrolysis and combustion of cellulosic materials. Adv. Carbohydr. Chem. 23: 419-474. doi:10.1016/ S0096-5332(08)60173-3.

Shafizadeh, F. 1971. Thermal behavior of carbohydrates. J. Polym. Sci. C Polym. Symp. 36(1): 21-51. doi:10.1002/polc.5070360105.

Shafizadeh, F., Chin, P.P.S., and DeGroot, W.F. 1977. Effective heat content of green forest fuels. For. Sci. 23(1): 81-89.

Simard, M., Romme, W.H., Griffin, J.M., and Turner, M.G. 2011. Do mountain pine beetle outbreaks change the probability of active crown fire in lodgepole pine forests? Ecol. Monogr. 81(1): 3-24. doi:10.1890/10-1176.1.

Susott, R.A. 1980. Thermal behavior of conifer needle extractives. For. Sci. 26(3): 347-360.

Susott, R.A. 1982. Characterization of the thermal properties of forest fuels by combustible gas analysis. For. Sci. 28: 404-420.

Undersander, D., Mertens, D.R., and Thiex, N. 2011. Forage analysis 
procedures [online]. Available from http://www.foragetesting.org [accessed 22 November 2011].

Van Wagner, C.E. 1972. Heat of combustion, heat yield and fire behavior. Can. For. Serv. Inf. Rep. PS-X-35.

Van Wagner, C.E. 1977. Conditions for the start and spread of crown fire. Can. J. For. Res. 7(1): 23-34. doi:10.1139/x77-004.

White, D.P. 1954. Variation in the nitrogen, phosphorus, and potassium contents of pine needles with season, crown position, and sample treatment. Proc. Soil Sci. Soc. Am. 18(3): 326-330. doi:10.2136/sssaj1954.03615995001800030024x.

White, R.H. 1987. Effect of lignin content and extractives on the higher heating value of wood. Wood Fiber Sci. 19(4): 446-452.
White, R.H., and Zipperer, W.C. 2010. Testing and classification of individual plants for fire behaviour: plant selection for the wildland-urban interface. Int. J. Wildland Fire, 19(2): 213-227. doi:10.1071/WF07128.

Williamson, N.M., and Agee, J.K. 2002. Heat content variation of interior Pacific Northwest conifer foliage. Int. J. Wildland Fire, 11(1): 91-94. doi:10.1071/WF01046.

Zar, J.H. 1999. Biostatistical analysis. 4th ed. Prentice Hall, Englewood Cliffs, New Jersey. 